\title{
ACPD
}

\section{Size-resolved and integral measurements of cloud condensation nuclei (CCN) at the high-alpine site Jungfraujoch}

\section{$\mathrm{CCN}$ at the Jungfraujoch}

D. Rose et al.

D. Rose ${ }^{1}$, S. S. Gunthe ${ }^{1,2}$, Z. Jurányi ${ }^{3,4}$, M. Gysel ${ }^{3}$, G. P. Frank ${ }^{1,5}$, J. Schneider ${ }^{1}$, J. Curtius ${ }^{6,7}$, and U. Pöschl ${ }^{1}$

${ }^{1}$ Max Planck Institute for Chemistry, Mainz, Germany

${ }^{2}$ Department of Civil Engineering, Indian Institute of Technology Madras, Chennai, India

${ }^{3}$ Laboratory of Atmospheric Chemistry, Paul Scherrer Institute, Villigen, Switzerland

${ }^{4}$ Institute of Aerosol and Sensor Technology, University of Applied Sciences Northwestern Switzerland, Windisch, Switzerland

${ }^{5}$ Department of Physics, Lund University, Lund, Sweden

${ }^{6}$ Institute of Atmospheric Physics, University of Mainz, Mainz, Germany

${ }^{7}$ Institute for Atmospheric and Environmental Sciences, Goethe University of Frankfurt am Main, Frankfurt am Main, Germany

Received: 18 November 2013 - Accepted: 25 November 2013

Interactive Discussion

Abstract

Conclusions

Tables

14

$\triangleleft$

Back

Full Screen / Esc

\section{Printer-friendly Version}


- Published: 10 December 2013

Correspondence to: D. Rose (d.rose@mpic.de)

Published by Copernicus Publications on behalf of the European Geosciences Union.

ACPD

13, 32575-32624, 2013

$\mathrm{CCN}$ at the Jungfraujoch

D. Rose et al.

Title Page

Abstract

Introduction

Conclusions

References

Tables

Figures

14 $>1$

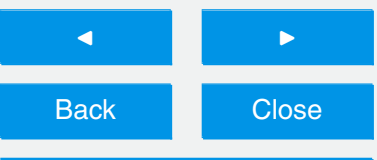

Full Screen / Esc

Printer-friendly Version

Interactive Discussion

(c) (1) 


\section{Abstract}

As part of the CLACE-6 campaign we performed size-resolved CCN measurements for a supersaturation range of $S=0.079 \%$ to $0.66 \%$ at the high-alpine research station Jungfraujoch, Switzerland, in March 2007. The derived effective hygroscopicity param5 eter $k$ describing the influence of particle composition on CCN activity was on average $0.23-0.30$ for Aitken $(50-100 \mathrm{~nm})$ and $0.32-0.43$ for accumulation mode particles $(100-200 \mathrm{~nm})$. The campaign average value of $k=0.3$ is similar to the average value of $k$ for other continental locations. When air masses came from southeasterly directions crossing the Po Valley in Italy, particles were much more hygroscopic $(k \approx 0.42)$ large sulfate mass fractions. The $k$ values obtained at $S=0.079 \%$ exhibited a good negative correlation with the organic mass fractions derived from $\mathrm{PM}_{1}$ aerosol mass spectrometer (AMS) measurements. Applying a simple mixing rule the organic and inorganic mass fractions observed by the AMS could be used to reproduce the temporal fluctuations of the hygroscopicity of accumulation mode particles quite well.

We show how during a cloud event the aerosol particles were activated as cloud droplets and then removed from the air by precipitation leaving behind only a small amount of accumulation mode particles consisting mainly of weakly $\mathrm{CCN}$-active particles, most likely externally mixed unprocessed soot particles.

During the campaign we had the opportunity to directly compare two DMT CCN counters for a certain time. The total $\mathrm{CCN}$ concentration $\left(N_{\mathrm{CCN} \text {,tot }}\right)$ obtained by the two instruments at equal supersaturations agreed well for both possible operating modes: detecting $N_{\mathrm{CCN} \text {,tot }}$ directly by sampling the polydisperse aerosol with the CCNC, or indirectly by combining size-resolved measurements of the activated fraction with parallel measurements of the particle size distribution (e.g., by SMPS). However, some 25 supersaturation setpoints differed between the two CCNCs by as much as $20 \%$ after applying the instrument calibrations, which resulted in differences of the corresponding $N_{\mathrm{CCN} \text {,tot }}$ of up to $50 \%$. This emphasizes that it is extremely important to carefully calibrate the supersaturation of the instrument, especially at low $S$.
ACPD

13, 32575-32624, 2013

$\mathrm{CCN}$ at the

Jungfraujoch

D. Rose et al.

Title Page

Abstract

Introduction

Conclusions

References

Tables

Figures

14

I

4

Back

$>$

Close

Full Screen / Esc

Printer-friendly Version

Interactive Discussion 


\section{Introduction}

Atmospheric aerosol particles that enable the condensation of water vapor and thus form cloud droplets are called cloud condensation nuclei (CCN). They indirectly influence the Earth's climate by determining cloud microphysics, the formation of precipita5 tion and cloud radiative properties (cloud albedo) (e.g., Lohmann and Feichter, 2005). The response of cloud characteristics and precipitation processes to increasing anthropogenic aerosol concentrations represents one of the largest uncertainties in the current understanding of climate change (IPCC, 2007). Therefore it is crucial to understand the factors that influence the properties and abundance of CCN. Since the temporal and spatial distribution of CCN is highly variable it is necessary to perform measurements at various seasons and locations to improve the incorporation of CCN in meteorological cloud and climate models.

Numerous papers have reported CCN measurements from various regions around the world, including marine, remote continental, and highly polluted environments. In most of these studies, the total CCN concentration is directly measured by a CCN counter at different supersaturation levels. Only recently, the numbers of studies increased, in which the CCN activation of ambient aerosol was examined with size resolution (e.g., Dusek et al., 2006; Kuwata et al., 2007, 2008, 2009; Kuwata and Kondo, 2008; Gunthe et al., 2009; Dusek et al., 2010; Rose et al., 2010; Bougiatioti et al., 2011; Bukowiecki et al., 2011; Cerully et al., 2011; Deng et al., 2011; Gunthe et al., 2011; Irwin et al., 2011; Kim et al., 2011; Rose et al., 2011; Padró et al., 2012; Zhang et al., 2012; Deng et al., 2013; Hong et al., 2013; Jurányi et al., 2013; Lance et al., 2013; Wu et al., 2013). The size-resolved CCN measurements, however, reveal additional information about the mixing state with regard to particle hygroscopicity/CCN activity, which et al., 2011; Padró et al., 2012).

The high-alpine research station Jungfraujoch in Switzerland provides the opportunity to measure continental background aerosols since most of the time the station is
ACPD

13, 32575-32624, 2013

$\mathrm{CCN}$ at the

Jungfraujoch

D. Rose et al.

Title Page

Abstract

Introduction

Conclusions

References

Tables

Figures

14

$>1$

4

Back

$>$

Close

Full Screen / Esc

Printer-friendly Version

Interactive Discussion 
located in the free troposphere but sometimes it is also influenced by injections from the planetary boundary layer (Collaud Coen et al., 2011). The hygroscopicity and CCN activity of aerosol particles as well as their activation behavior in ambient clouds have been investigated at the Jungfraujoch for several years (e.g., Henning et al., 2002;

5 Nessler et al., 2003; Cozic et al., 2007; Sjogren et al., 2008; Kammermann et al., 2010; Jurányi et al., 2010, 2011; Hammer et al., 2013). These studies found that there is only little seasonal trend in the hygroscopicity and CCN activity. On the other hand the number fraction of particles that can be activated under a certain water vapor supersaturation exhibits a significant seasonal cycle due to strong seasonal variations of the 10 number fraction of larger particles. During influence from the planetary boundary layer, the hygroscopicity and CCN activity are slightly reduced. Measurements on the mixing state of particles have been investigated only under sub-saturated conditions yet. Overall, it has been found that the observed chemical composition, the hygroscopic growth, and the CCN activity are generally consistent.

15 In this study, we present size-resolved CCN measurements on the Jungfraujoch performed during the CLACE- 6 campaign in March 2007. We relate the CCN properties to the meteorological conditions and compare them with measurements of the particles' chemical composition.

\section{Methods}

\subsection{Measurement location}

Measurements were performed over the period of 3-13 March 2007 at the Global Atmosphere Watch (GAW) laboratory of the high-alpine research station Jungfraujoch (JFJ hereafter, 3580 m a.s.I., $46.548^{\circ} \mathrm{N}, 7.984^{\circ} \mathrm{E}$, see Fig. 1) in Switzerland and were part of the "CLoud and Aerosol Characterization Experiment" in 2007 (CLACE-6). Because of the station elevation the JFJ is considered to be prevalently in the free troposphere and therefore suited for the measurement of background aerosol (Nyeki et al.,

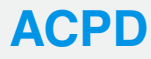

13, 32575-32624, 2013

$\mathrm{CCN}$ at the

Jungfraujoch

D. Rose et al.

Title Page

Abstract

Introduction

Conclusions

References

Tables

Figures

14

$\Delta \mathbf{I}$

4

Back

$\triangleright$

Close

Full Screen / Esc

Printer-friendly Version

Interactive Discussion 
1998). Nevertheless, convective anticyclonic and convective indifferent weather situations, which occur mostly from April to September, influence the JFJ through injections of air parcels from the planetary boundary layer. Therefore aerosol concentrations exhibit a seasonal cycle with a maximum in summer and a minimum in the winter (Col5 laud Coen et al., 2011). More detailed information about the JFJ site and long term measurements of aerosols can be found in Baltensperger et al. (1997); Cozic et al. (2008) and Collaud Coen et al. $(2007,2011)$.

\subsection{Meteorological conditions}

The average meteorological parameters (arithmetic mean \pm standard deviation) recorded during the CCN measurement period near the aerosol inlet were: $(262 \pm 3) \mathrm{K}$ ambient temperature, $(65 \pm 33) \%$ ambient relative humidity, and $(653 \pm 5) \mathrm{hPa}$ ambient pressure. The time series of the basic meteorological parameters displayed in Fig. A1 do not indicate any diurnal cycle. Except during two periods with clear south easterly winds (6-7 March and 11-13 March), the local wind direction fluctuated a lot. The measurement site was in clouds on $60-65 \%$ of the time during the campaign period.

Three-day backward trajectories were calculated from the HYSPLIT Trajectory Model by NOAA ARL (http://ready.arl.noaa.gov/HYSPLIT.php) using the global GDAS meteorological data with a start height of $3500 \mathrm{~m}$ a.s.l., which were in accordance with the Alpine Weather Statistic (AWS) synoptic weather classification system (Schüpp, 1979).

20 Figure 1 shows that the air masses came from several directions during the measurement period. In the beginning (3-6 March) air masses came mainly from westerly directions predominantly crossing central and south France. From 8-11 March air masses came mostly from northerly directions (over Germany and the Netherlands), and in the end (11-13 March) air masses came from easterly directions crossing northern Italy
ACPD

13, 32575-32624, 2013

CCN at the

Jungfraujoch

D. Rose et al.

Title Page

Abstract

Introduction

Conclusions

References

Tables

Figures

14

I

4

Back

Close

Full Screen / Esc

Printer-friendly Version

Interactive Discussion 


\subsection{Instrumentation and data processing}

\subsubsection{Aerosol inlet}

During the CLACE- 6 campaign three different types of aerosol inlets were used sampling ice nuclei (Ice-CVI, Mertes et al., 2007), interstitial particles (non-activated par5 ticles inside clouds $<2.5 \mu \mathrm{m}$ in diameter) and total particles (interstitial particles and cloud residuals). In this study we used only data recorded by sampling through the total aerosol inlet and interstitial inlet.

The total aerosol inlet consisted of a heated and insulated vertical stainless-steel tube (length: $2 \mathrm{~m}$, diameter: $6 \mathrm{~cm}$ ) and a heated snow-hood (Weingartner et al., 1999).

10 The sampled air was heated to $25^{\circ} \mathrm{C}$ in order to evaporate any water from hydrometeors (cloud droplets and ice crystals), thereby releasing the residual particles. During cloud events, the aerosol sampled at the total inlet thus consisted of both the residual particles from dried hydrometeors as well as the inactivated (interstitial) particles. The interstitial inlet consisted of a cyclone with a $2.5 \mu \mathrm{m}$ cut-off $\left(\mathrm{PM}_{2.5}\right)$ segregating all hydrometeors with a diameter $>2.5 \mu \mathrm{m}$ and letting through only smaller, unactivated particles. During cloud-free periods the aerosol sampled through the interstitial inlet corresponded to the total aerosol.

Right below the inlet, the sampling line was split into separate lines. One led to the CCN measurement setup ( $\sim 8 \mathrm{~m}$ length of sampling line), and to the aerosol mass 20 spectrometer setup ( $\sim 5 \mathrm{~m}$ length of sampling line). Another one was used for aerosol particle size distribution measurements (SMPS, $\sim 1 \mathrm{~m}$ length of sampling line).

\subsubsection{Cloud condensation nuclei (CCN)}

Two continuous flow CCN counters (DMT CCNC, Roberts and Nenes, 2005; Lance et al., 2006) operated by the Max Planck Institute for Chemistry and the Paul Scherrer Institute (MPI CCNC and PSI CCNC, respectively) were measuring the activation of aerosol particles to cloud droplets at different water vapor supersaturations. During the

$\mathrm{CCN}$ at the Jungfraujoch

D. Rose et al.

Title Page

Abstract Introduction

Conclusions References

Tables Figures

14

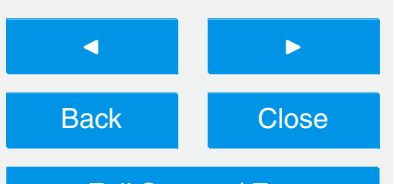

Full Screen / Esc

Printer-friendly Version

Interactive Discussion 
campaign the PSI CCNC was used solely in a polydisperse mode detecting the total number concentration of $\mathrm{CCN}\left(N_{\mathrm{CCN} \text {,tot }}\right)$ at a defined supersaturation. The MPI CCNC was mainly operated in a monodisperse mode, for which it was coupled to a differential mobility analyzer (DMA; TSI 3071; sheath flow $10 \mathrm{Lmin}^{-1}$; sample flow $1.8 \mathrm{Lmin}^{-1}$ ) 5 and a condensation particle counter (CPC; TSI 3762; sample flow $1.0 \mathrm{~L} \mathrm{~min}^{-1}$ ). In the monodisperse mode, the aerosol first passed through a bipolar charger (Ni-63, $555 \mathrm{MBq}$ ) to reach charge equilibrium. Then, the charged aerosol entered the DMA where particles of a certain electrical mobility (corresponding to a certain particle size) were selected and sent to the CPC and the CCNC to measure in parallel the aerosol 10 particle number concentration $\left(N_{\mathrm{CN}}\right)$ and the number concentration of particles that can act as CCN $\left(N_{\mathrm{CCN}}\right)$, respectively, (i.e., size-resolved CCN efficiency spectra or activation curves; Frank et al., 2006; Rose et al., 2008). Only at the end of the campaign the MPI CCNC was also used in a polydisperse mode for about $15 \mathrm{~h}$.

The MPI CCNC and PSI CCNC were operated at a total flow rate of $0.8 \mathrm{Lmin}^{-1}$ 15 and $1.0 \mathrm{Lmin}^{-1}$, respectively, both with a sheath-to-aerosol flow ratio of 10 . The water vapor supersaturation $(S)$ in the CCNC, which is determined by the temperature difference between the upper and lower end of the CCNC flow column $(\Delta T)$, was calibrated using size-selected ammonium sulfate particles according to the procedure described by Rose et al. (2008) and using their Köhler model AP3 for calculation of the thermodynamic properties. The calibrated supersaturation set points were $0.079 \%, 0.17 \%$, $0.27 \%, 0.46 \%$, and $0.66 \%$ for the MPI CCNC and $0.099 \%, 0.20 \%, 0.29 \%, 0.48 \%$, and $0.67 \%$ for the PSI CCNC (relative uncertainty $\Delta S / S<10 \%$ for each CCNC). The two CCNCs sampled aerosol particles only through the total aerosol inlet.

\section{Monodisperse CCN measurements}

25 For each measurement cycle in the monodisperse mode, $\Delta T$ was set to 5 different levels $(2.4-9.3 \mathrm{~K})$ corresponding to $S$ values in the range of $0.079-0.66 \%$ (MPI CCNC). For each $\Delta T$ and $S$, respectively, the diameter of the dry aerosol particles $(D)$ selected by the DMA was set to 6 different values in the range of $20-250 \mathrm{~nm}$ depending on the 32582

\section{ACPD}

13, 32575-32624, 2013

$\mathrm{CCN}$ at the

Jungfraujoch

D. Rose et al.

Title Page

Abstract

Introduction

Conclusions

References

Tables

Figures

14

$\Delta$

4

Back

$\checkmark$

Close

Full Screen / Esc

Printer-friendly Version

Interactive Discussion 
supersaturation selected. At each $D$, the size-resolved number concentration of aerosol particles (condensation nuclei, $\mathrm{CN}$ ), $N_{\mathrm{CN}}$, was measured with the CPC, and the sizeresolved number concentration of $\mathrm{CCN}, N_{\mathrm{CCN}}$, was measured with the CCNC. The integration time for each measurement data point was $190 \mathrm{~s}$, the recording of a CCN 5 efficiency spectrum $\left(N_{\mathrm{CCN}} / N_{\mathrm{CN}}\right.$ vs. $\left.D\right)$ took $\sim 30 \mathrm{~min}$ (including $50 \mathrm{~s}$ adjustment time for each new particle size and $6 \mathrm{~min}$ for adjustment to the next supersaturation level). The completion of a full measurement cycle comprising CCN efficiency spectra at 5 different supersaturation levels took $\sim 155 \mathrm{~min}$ (including another $5 \mathrm{~min}$ of settling time for the changeover from highest to lowest $S$ ). During the CLACE-6 campaign about 1080 cycles of monodisperse measurements were performed with the MPI CCNC with occasional short term interruptions for instrument calibration and maintenance.

The measurement data of the CCN efficiency spectra were corrected for the effects of multiply charged particles as described by Rose et al. $(2008,2010)$, and the corrected data were used for further analysis. For the charge correction we used aerosol particle number size distributions that were measured in parallel by a scanning mobility particle sizer (SMPS; custom-built and validated during an SMPS intercomparison workshop (Wiedensohler et al., 2012); scanning between $17 \mathrm{~nm}$ and $470 \mathrm{~nm}$ mobility equivalent diameter), which was operated directly below the total aerosol inlet (see Sect. 2.3.1). For the times at which no SMPS data were available ( $35 \%$ of the scans) we performed no charge correction. Nevertheless, the CCN data from these periods remained comparable with the rest of the days, as the effects of the charge correction were generally small $(<5 \%$ change in activation diameter and other parameters used for further calculations). We also corrected the CCN efficiency spectra for differences in the CCNC and CPC counting efficiencies by using a constant correction factor $f_{\text {corr }}=1.04$, which we obtained from the supersaturation calibration experiments (Rose et al., 2010). The uncertainties of $N_{\mathrm{CCN}}, N_{\mathrm{CN}}$ and $N_{\mathrm{CCN}} / N_{\mathrm{CN}}$ are estimated to be $<20 \%$ for individual measurement data points and $<10 \%$ for average values and fit parameters (Rose et al., 2008, 2010). Due to the low particle number concentrations
ACPD

13, 32575-32624, 2013

$\mathrm{CCN}$ at the

Jungfraujoch

D. Rose et al.

Title Page

Abstract

Introduction

Conclusions

References

Tables

Figures

14

$\Delta$

4

Back

$\triangleright$

Close

Full Screen / Esc

Printer-friendly Version

Interactive Discussion 
prevailing at the JFJ, the CCN concentrations measured at the smallest particle diameters $(<40 \mathrm{~nm})$ were affected by low signal-to-noise ratios and were therefore omitted.

Each corrected CCN efficiency spectrum was fitted with a 3-parameter cumulative Gaussian distribution function (CDF), from which the following parameters were de5 rived (Rose et al., 2010): the maximum activated fraction MAF, the midpoint activation diameter $D_{\mathrm{a}}$, and the standard deviation $\sigma_{\mathrm{a}}$. The CDF standard deviation is a general indicator for the extent of mixing, i.e., for the heterogeneity of the particle composition in the investigated aerosol. Under ideal conditions, $\sigma_{\mathrm{a}}$ should be zero for an internally mixed aerosol with particles of homogeneous chemical composition. Even calibration 10 aerosols composed of high-purity ammonium sulfate exhibit small non-zero $\sigma_{\mathrm{a}}$ values that correspond to $\sim 3 \%$ of $D_{\mathrm{a}}$ and can be attributed to heterogeneities of the water vapor supersaturation profile in the CCNC, finite width of the DMA's transfer function, or particle shape effects. Thus, normalized CDF standard deviation or "heterogeneity parameter" values of $\sigma_{\mathrm{a}} / D_{\mathrm{a}} \approx 3 \%$ indicate internally mixed homogeneous $\mathrm{CCN}$ whereas 15 higher values indicate mixtures of particles with different chemical composition and hygroscopicity (Rose et al., 2010, 2011).

For all data pairs of supersaturation $S$ and activation diameter $D_{a}$ derived from the CCN efficiency spectra measured in this study, the effective hygroscopicity parameter $\kappa_{\mathrm{a}}$ (Petters and Kreidenweis, 2007; Pöschl et al., 2009) was calculated using the $20 \quad k$-Köhler model equations and parameters specified in Rose et al. (2010) (surface tension of $0.072 \mathrm{~J} \mathrm{~m}^{-2}$, temperature of $303 \mathrm{~K}$ ). The parameter $\kappa_{\mathrm{a}}$ characterizes the average hygroscopicity of $\mathrm{CCN}$-active particles in the size range around $D_{\mathrm{a}}$. The statistical uncertainty in the determination of activation diameters by curve fitting (standard error of the CDF fit parameters) was on average $\sim 2-3 \mathrm{~nm}(\sim 1-5 \%)$. According to the relative 25 sensitivities specified by Kreidenweis et al. (2009), the uncertainty of $1-5 \%$ in diameter corresponds to an uncertainty of $3-15 \%$ in $k$, and the uncertainty of $<10 \%$ in supersaturation reported above corresponds to an uncertainty of $<20 \%$ in $k$.

The deviation of MAF from unity represents the number fraction of externally mixed $\mathrm{CCN}$-inactive particles at the largest diameter measured $\left(D_{\max }\right)$ and the nearby diam-

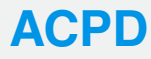

13, 32575-32624, 2013

CCN at the

Jungfraujoch

D. Rose et al.

Title Page

Abstract

Introduction

Conclusions

References

Tables

Figures

14

$\Delta$

4

Back

$>$

Close

Full Screen / Esc

Printer-friendly Version

Interactive Discussion 
eter range with a plateau of activated particle fraction (Gunthe et al., 2011). Particles that are $\mathrm{CCN}$-inactive at $D_{\max }$ can be regarded as weakly CCN-active particles with hygroscopicity parameters below the threshold value $k_{\mathrm{c}}=\kappa\left(D_{\max }, S\right)$ (Su et al., 2010).

CCN number size distributions $\left(\mathrm{d} N_{\mathrm{CCN}} / \mathrm{d} \log D\right)$ at a certain supersaturation were

5 calculated by multiplying the CCN efficiency spectra (3-parameter CDF fits of $\left.N_{\mathrm{CCN}} / N_{\mathrm{CN}}\right)$ measured at this $S$ with the aerosol particle (CN) number size distributions $\left(\mathrm{d} N_{\mathrm{CN}} / \mathrm{d} \log D\right)$ measured in parallel. From the monodisperse measurements, total CCN number concentrations at a certain supersaturation $\left(N_{\mathrm{CCN}, \text { tot, } \mathrm{m}}\right)$ were calculated by stepwise integration of the $\mathrm{CCN}$ number size distributions across the whole 10 diameter range (for further details see Rose et al., 2010). Note that a list of frequently used symbols can be found in Table A1.

\section{Polydisperse CCN measurements}

For each measurement cycle in the polydisperse mode, the temperature difference in the CCNC, $\Delta T$, was set to 5 different levels corresponding to $S$ values in the range of $0.099-0.67 \%$ for the PSI CCNC and $0.079-0.66 \%$ for the MPI CCNC. The PSI CCNC was operated in the polydisperse mode during the entire campaign, whereas the MPI CCNC was operated in this mode only from 13 March 18:00 LT to 14 March 09:30 LT. The total CCN concentration from polydisperse measurements $\left(N_{\mathrm{CCN}, \text { tot,p }}\right)$ at a certain supersaturation was recorded with $1 \mathrm{~Hz}$. It was averaged over 8 min sampling 20 time and the recording of a full cycle of 5 supersaturations took 60 min including $3 \mathrm{~min}$ adjustment time for switching to the next supersaturation level and 5 min extra time for switching from highest to lowest supersaturation.

Since the sampling line between the inlet and the $\mathrm{CCN}$ instruments was rather long (see Sect. 2.3.1) it would be necessary to correct the measurements of $N_{\mathrm{CCN}, \text { tot, }}$ for diffusional losses. This is, however, not possible, because these kind of losses are size dependent and no information about the particle size is provided in the direct

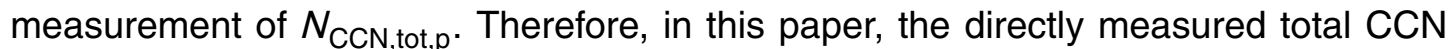
concentration $\left(N_{\mathrm{CCN} \text {,tot,p }}\right)$ is only used for the comparison of the two CCNCs. Note

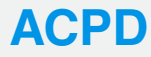

13, 32575-32624, 2013

CCN at the

Jungfraujoch

D. Rose et al.

Title Page

Abstract

Introduction

Conclusions

References

Tables

Figures

14

$\rightarrow 1$

4

Back

Full Screen / Esc

Printer-friendly Version

Interactive Discussion 
that the total $\mathrm{CCN}$ number concentration that is calculated from $\mathrm{d} N_{\mathrm{CCN}} / \mathrm{d} \log D$, i.e. $N_{\mathrm{CCN}, \mathrm{tot}, \mathrm{m}}$, is independent of any sampling losses between total aerosol inlet and the CCNC, because it is referred to CN size distributions as obtained with the SMPS right below the aerosol inlet (Sects. 2.3.1 and 2.3.2).

\section{2.3.3 Aerosol mass spectrometry (AMS)}

An Aerodyne High-Resolution Time-of-Flight Aerosol Mass Spectrometer (HR-ToFAMS, hereafter short AMS) was used to measure the chemical composition of nonrefractory submicron aerosol particles. The data set used in this study includes all times when the AMS was either attached to the total inlet or to the interstitial inlet dur-

10 ing cloud-free passages, i.e., the sampled aerosol could be always regarded as total aerosol.

The AMS was described in detail by DeCarlo et al. (2006) and Canagaratna et al. (2007). Briefly, it samples particles in the size range between 40 and $1000 \mathrm{~nm}$ (vacuum aerodynamic diameter $\left(D_{\mathrm{va}}\right)$, see DeCarlo et al., 2004) through a critical orifice $(120 \mu \mathrm{m}$ 15 for Jungfraujoch pressure conditions) and an aerodynamic lens and evaporates the particles on a hot surface $\left(\sim 600^{\circ} \mathrm{C}\right)$. The evaporated molecules are ionized by electron impact, and the ions are analyzed by a high resolution time-of-flight mass spectrometer. Calibration of peak intensities with test aerosol (ammonium nitrate) allows for conversion of the measured peak height into quantitative mass loadings. Detected aerosol 20 species are particulate organic matter $(\mathrm{Org})$, as well as particulate sulfate $\left(\mathrm{SO}_{4}^{2-}\right)$, nitrate $\left(\mathrm{NO}_{3}^{-}\right)$, ammonium $\left(\mathrm{NH}_{4}^{+}\right)$, and chloride $\left(\mathrm{Cl}^{-}\right)$. The collection efficiency with respect to particle bounce (e.g., Matthew et al., 2008; Middlebrook et al., 2012) was set to 0.5 for this dataset.

Due to the low particle mass concentration levels at the JFJ, it was necessary to integrate over the entire particle size range to obtain time series of the mass concentrations of individual species as well as organic and inorganic mass fractions ( $f_{\text {org }}$, $\left.f_{\text {inorg }}\right)$. Size-resolved chemical composition was determined only as an average for the
ACPD

13, 32575-32624, 2013

$\mathrm{CCN}$ at the

Jungfraujoch

D. Rose et al.

Title Page

Abstract

Introduction

Conclusions

References

Tables

Figures

14

$\Delta$

4

Back

Close

Full Screen / Esc

Printer-friendly Version

Interactive Discussion 
measurement period discussed in this study. Due to the particularly high scatter, the ammonium size distribution was smoothed by scaling with the nitrate size distribution.

Complementary information on the chemical composition of particles observed at the JFJ can be found e.g., in Henning et al. (2003); Cozic et al. (2007, 2008); Cziczo 5 et al. (2009); Kamphus et al. (2010); Liu et al. (2010) and Ebert et al. (2011).

\section{Results}

\subsection{Intercomparison of the two $\mathrm{CCN}$ counters}

For a certain time during the CLACE-6 campaign we operated two DMT CCNCs in parallel (MPI CCNC, and PSI CCNC) to test and compare our used calibration and data 10 analysis methods. The two instruments were operated at equal (uncalibrated) nominal supersaturation, unfortunately resulting in different true supersaturation setpoints. For the highest three $S$ levels, the (calibrated or true) supersaturation in the MPI CCNC was only slightly lower than in the PSI CCNC $(<10 \%)$, but for the two lowest $S$ levels, the difference in $S$ was more significant (15-20\% lower in MPI than in PSI CCNC).

15 Figure 2a displays a scatter plot of the total CCN concentrations measured by the MPI and the PSI CCNC when both instruments were operated in the polydisperse mode $\left(N_{\mathrm{CCN}, \text { tot,p }}\right)$, i. e., when they both measured the number concentration of CCN directly, without size-segregation of the particles. For all $S$, the CCN number concentrations measured by the MPI and the PSI CCNC exhibited a very good correlation $\left(R^{2}>0.99\right)$.

20 For the three highest $S$ levels the values of $N_{\text {CCN,tot,p }}$ agreed very well (on average MPI $\sim 6 \%$ smaller than PSI, Table 2). For the two lowest $S$, however, the MPI CCNC measured significantly lower concentrations (on average up to $\sim 50 \%$ at lowest $S$ ). This enormous difference can be explained by comparing $N_{\mathrm{CCN}, \text { tot,p }}$ measured at different supersaturations $(\sim 20 \%$ difference in $S$ between MPI and PSI CCNC at the lowest level). The strong dependence of $N_{\mathrm{CCN} \text {,tot }}$ on $S$ at low levels implies that careful CCNC calibration is crucial, particularly at low $S$ (Rose et al., 2008), similar to the fact that
ACPD

13, 32575-32624, 2013

$\mathrm{CCN}$ at the

Jungfraujoch

D. Rose et al.

Title Page

Abstract

Introduction

Conclusions

References

Tables

Figures

14

$\rightarrow 1$

4

Back

Full Screen / Esc

Printer-friendly Version

Interactive Discussion 
$N_{\mathrm{CCN}, \text { tot }}$ is more sensitive to the mean particle hygroscopicity in this supersaturation range (Jurányi et al., 2010).

Figure $2 \mathrm{~b}$ shows the comparison of the CCN concentrations measured by MPI and PSI CCNC when the MPI CCNC was operated in a monodisperse/size resolved mode 5 (Sect. 2.3.2) and the PSI CCNC was operated in a polydisperse mode. Note that for this comparison the aerosol particle size distribution $\left(\mathrm{d} N_{\mathrm{CN}} / \mathrm{d} \log D\right.$; measured by SMPS right below the aerosol inlet) used for the calculation of the total MPI CCN number concentration $\left(N_{\mathrm{CCN} \text {,tot, }}(\mathrm{MPI})\right)$ was corrected for diffusional losses along the sampling line of the PSI CCNC. As expected the data points exhibited a linear correlation, but with 10 a smaller correlation coefficient $\left(R^{2} \sim 0.84\right.$ over all $S$ levels) than for the comparison shown in Fig. 2a. The main reason for additional scatter is most likely associated with problems to get different measurements with low time resolution to match. The SMPS, polydisperse CCNC (PSI), and monodisperse CCNC (MPI) have time resolutions of $6 \mathrm{~min}, 1 \mathrm{~h}$ (all $S$ ), and $2.5 \mathrm{~h}$ (all $S$ ), respectively.

15 Except for the lowest $S$, the MPI CCN number concentration was larger than the PSI concentration (on average $\sim 20 \%$ for the three highest $S$, Table 2). Accounting for the difference in the supersaturation of the two CCNCs, i.e., subtracting the average difference in the $\mathrm{CCN}$ number concentration as determined in the comparison of polydisperse measurements $\left(N_{\mathrm{CCN} \text {,tot,p }}\right)$, the MPI CCN number concentration was on 20 average $20 \%$ to $30 \%$ higher than the PSI concentration. This overestimation was independent of $S$. The high bias can be most likely explained by the high uncertainty that is involved in the calculation of $N_{\mathrm{CCN}, \text { tot, } \mathrm{m}}$ by integrating the $\mathrm{CCN}$ number size distribution. It is known that already the determination of the total particle number concentration by integrating the particle number size distribution measured by SMPS $\left(\mathrm{d} N N_{\mathrm{CN}} / \mathrm{d} \log D\right)$ 25 has an uncertainty of 10-20\% compared to direct measurements by a CPC (Wiedensohler et al., 2012). Another reason for the discrepancy between $N_{\mathrm{CCN}, \text { tot, } \mathrm{m}}(\mathrm{MPI})$ and $N_{\mathrm{CCN}, \text { tot, }}(\mathrm{PSI})$ might be that the diffusion correction of the particle number size distribution along the long sampling line was not sufficient.

\section{ACPD}

13, 32575-32624, 2013

$\mathrm{CCN}$ at the

Jungfraujoch

D. Rose et al.

Title Page

Abstract

Introduction

Conclusions

References

Tables

Figures

14

$\Delta$

4

Back

$\triangleright$

Close

Full Screen / Esc

Printer-friendly Version

Interactive Discussion 
To date only a few studies have compared total CCN number concentrations observed by poly and monodisperse CCN measurements, all of them reporting similarly good agreement between the two approaches as our study: Moore et al. (2010) observed relative deviations of $\sim 10-20 \%$ at a total concentration level of $\sim 1000 \mathrm{~cm}^{-3}$ 5 and a supersaturation of $0.3 \%$. In a supersaturation range of $0.06 \%$ to $0.7 \%$, Deng et al. (2011) found on average a $19 \%$ over-estimation of mono compared to polydisperse measurements, which they attributed to water depletion in the CCNC due to the high particle concentrations (on the order of $10^{3}-10^{4} \mathrm{~cm}^{-3}$ ). Zhang et al. (2012) operated a DMT CCNC-200 using one supersaturation column for polydisperse and one for 10 monodisperse CCN measurements. In a supersaturation range of $0.1 \%$ to $0.4 \%$ and a concentration range of $2000-15000 \mathrm{~cm}^{-3}$, they reported correlations with a slope of 0.7 to 1 . In Jurányi et al. (2013), the two methods correlated with slopes of 0.96-1.05 $\left(R^{2}=0.75-0.84\right)$ for a supersaturation range of $0.2 \%$ to $0.4 \%$ and a concentration range of $100-5000 \mathrm{~cm}^{-3}$.

\subsection{Averages over the entire measurement period}

\subsubsection{CCN efficiency spectra and size distributions}

Figure 3a shows the average measured CCN efficiency spectra over the entire measurement period (3 to 13 March 2007) at different supersaturation levels. The average parameters derived from the CCN efficiency spectra are summarized in Table 2 (arith20 metic mean value \pm standard deviation).

The midpoint activation diameters $D_{a}$ increased with decreasing $S$ and were larger than the critical diameters for CCN activation of pure ammonium sulfate particles at the given supersaturation levels. The heterogeneity parameter $\left(\sigma_{\mathrm{a}} / D_{\mathrm{a}}\right)$ increased from 0.09 to 0.20 with increasing $S$ (i.e., with decreasing particle size) indicating that larger particles were more homogeneously mixed than smaller ones. The average CCN efficiency spectra reached a MAF of unity also for the lowest $S$, which is in contrast to what has often been observed in the past for other size-resolved CCN measurements

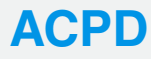

13, 32575-32624, 2013

$\mathrm{CCN}$ at the

Jungfraujoch

D. Rose et al.

Title Page

Abstract

Introduction

Conclusions

References

Tables

Figures

14

$\rightarrow 1$

4

Back

Full Screen / Esc

Printer-friendly Version

Interactive Discussion 
in continental regions (e.g. Gunthe et al., 2011; Rose et al., 2010, 2011; Paramonov et al., 2013), whose average spectra approached only $\sim 0.9$ and lower.

In Fig. 3b, the number size distributions averaged over the entire measurement period are shown for aerosol particles $(\mathrm{CN})$ and for $\mathrm{CCN}$ at different supersaturation lev5 els. The corresponding average values (mean value \pm standard deviation) of the total $\mathrm{CN}$ number concentration $\left(N_{\mathrm{CN} \text {,tot }}\right.$, integrated between 17 and $\left.470 \mathrm{~nm}\right)$, the total CCN number concentration $\left(N_{\mathrm{CCN}, \text { tot, } \mathrm{m}}\right)$, and the CCN efficiency $\left(N_{\mathrm{CCN}, \text { tot, } \mathrm{m}} / N_{\mathrm{CN} \text {,tot }}\right)$ for each supersaturation level are summarized in Table 2.

The average $\mathrm{CN}$ number size distribution for the entire measurement period was 10 dominated by two modes, one with a peak at 50 to $60 \mathrm{~nm}$ and another one at 120 to $140 \mathrm{~nm}$. The mean total $\mathrm{CN}$ number concentration (between 17 and $470 \mathrm{~nm}$ ) was $\sim 400 \mathrm{~cm}^{-3}$. As seen from the time series of the CN number size distribution (Fig. A2), the shape of the size distribution varied strongly during the measurement period. Occasionally, only an Aitken mode (peak around 40-60 nm, e.g., morning of 3, 9, and 1510 March), or only an accumulation mode (peak around 100-200 nm, e.g., noon of 4 March, evening of 5 March) was present.

At $S=0.079 \%$, the total CCN number concentration $\left(\sim 50 \mathrm{~cm}^{-3}\right)$ accounted on average for $\sim 13 \%$ of $N_{\mathrm{CN} \text {,tot }}$ because only a minor fraction of particles was larger than the activation diameter at this supersaturation $\left(D_{\mathrm{a}} \sim 170 \mathrm{~nm}\right)$. At $S=0.17-0.66 \%$, the activation diameters were at or below the diameter at which the accumulation mode peaks and the integral $C C N$ efficiencies were substantially higher $(\sim 0.3-0.6$; with $N_{\text {CCN,tot,m }} \approx 100-250 \mathrm{~cm}^{-3}$ ). The observed $\mathrm{CN}$ and $\mathrm{CCN}$ number concentrations are similar to other integral measurements at the JFJ (Jurányi et al., 2010, 2011); they are about the same as in other remote clean regions (Amazon Basin: Roberts et al., 2001; Gunthe et al., 2009); about one order of magnitude smaller than in polluted regions (European megacity, Paris: Jurányi et al., 2013); and about two orders of magnitude smaller than in very polluted regions (Chinese megacities: Rose et al., 2010; Gunthe et al., 2011).

ACPD

13, 32575-32624, 2013

$\mathrm{CCN}$ at the

Jungfraujoch

D. Rose et al.

Title Page

Abstract

Introduction

Conclusions

References

Tables

Figures

14

$\Delta$

4

Back

$\triangleright$

Close

Full Screen / Esc

Printer-friendly Version

Interactive Discussion 


\subsubsection{Hygroscopicity parameter}

The campaign average of the observed hygroscopicity parameter $\kappa_{\mathrm{a}}$ derived from the CCN efficiency spectra over all measured size ranges was 0.32 (Table 2). This is consistent with other measurements, estimates and model calculations for the effective average hygroscopicity of aerosols in continental regions (e.g., Andreae and Rosenfeld, 2008; Shinozuka et al., 2009; Pöschl et al., 2009; Chang et al., 2010; Pringle et al., 2010; Rose et al., 2010, 2011; Gunthe et al., 2011; Wu et al., 2013, and references therein). Figure 4 presents the average $\kappa_{\mathrm{a}}$ plotted vs. particle size, i.e., vs. the mean activation diameter observed for the different $S$-levels. It shows a pronounced size-dependence ranging from $k_{\mathrm{a}} \approx 0.2$ for Aitken mode particles around 50 to $70 \mathrm{~nm}$ up to $k_{\mathrm{a}} \approx 0.43$ for accumulation mode particles of $\sim 170 \mathrm{~nm}$ diameter. The observed $\kappa$ values and size-dependence are comparable with other observations at the JFJ by Jurányi et al. (2011) and Bukowiecki et al. (2011), who found an increasing particle hygroscopicity from $k \sim 0.15$ to 0.3 within a size range of 50 to $150 \mathrm{~nm}$.

The size dependence in $\kappa_{\mathrm{a}}$ resulted from differences in the chemical composition of the particles: as evident from Fig. 5 particles of diameters below $\sim 100 \mathrm{~nm}$ consisted on average mainly of organic material with relatively low hygroscopicity, whereas particles with $D>100 \mathrm{~nm}$ incorporated larger amounts of inorganic ions leading to higher particle hygroscopicity as will be discussed in Sect. 3.4.

20 The comparison with data of size-resolved CCN measurements from an earlier campaign at the Jungfraujoch (CLACE-5; February/March 2006; unpublished data) showed similar ranges for the hygroscopicity parameter $\kappa_{\mathrm{a}}$ (yellow data points in Fig. 4). In the investigated diameter range of $\sim 40-80 \mathrm{~nm} \kappa_{\mathrm{a}}$ increased from 0.26 to 0.37 . This is $\sim 20 \%$ higher than the average values, but well within the range of temporal fluc25 tuations observed during the CLACE- 6 campaign. It is still smaller than the average $\kappa_{\mathrm{a}}$ values observed during a polluted air flow from easterly directions during the measurements in 2007 (red data points in Fig. 4; more details in Sect. 3.3).
ACPD

13, 32575-32624, 2013

$\mathrm{CCN}$ at the

Jungfraujoch

D. Rose et al.

Title Page

Abstract

Introduction

Conclusions

References

Tables

Figures

14

$\rightarrow 1$

4

Back

Full Screen / Esc

Printer-friendly Version

Interactive Discussion 


\subsection{Time series and meteorological conditions}

Figure 6 shows the time series of several characteristic CCN parameters over the time period of 3 to 13 March with some interruptions due to technical difficulties and instrument maintenance. For better readability the parameters are plotted only for $0.079 \%$, $5 \quad 0.17 \%$, and $0.66 \%$ supersaturation. The values for $S=0.27 \%$ and $0.46 \%$ were generally in between those for $S=0.17 \%$ and $0.66 \%$. Note that the CCN parameters measured at different supersaturation levels represent the activation properties of the particles of different size ranges ( $S=0.079 \%$ to $0.17 \%: 100 \mathrm{~nm}$ to $200 \mathrm{~nm}, S=0.27 \%$ to $0.66 \%: 50 \mathrm{~nm}$ to $100 \mathrm{~nm}$ ).

All CCN parameters exhibited strong temporal variations: the hygroscopicity parameter $\kappa_{\mathrm{a}}$ varied between 0.1 and 0.7 ; the maximum activated fraction MAF was on average 1 but exhibited also very small values of $\sim 0.3$ (see Sect. 3.5 for detailed explanation); and $\sigma_{\mathrm{a}} / D_{\mathrm{a}}$ varied between 0.03 (quasi homogeneously mixed aerosol) to 0.4 (very heterogeneously mixed aerosol). The CCN concentration measured at every individual su5 persaturation level varied over one order of magnitude, from $\sim 10 \mathrm{~cm}^{-3}$ at $S=0.079 \%$ to $\sim 1000 \mathrm{~cm}^{-3}$ at $S=0.66 \%$. Also the total CCN efficiency varied strongly around the mean value obtained for the individual supersaturation levels.

To find out the reason for the temporal variations of the CCN parameters we compared them with different meteorological variables. We did not find any clear difference in the CCN properties with regard to the weather classification (convective cyclonic and advective or indifferent/anticyclonic convective weather types) as described in Collaud Coen et al. (2011). With regard to the origin of air masses (analysis of back trajectories), however, we could find distinct differences in the CCN properties. As detailed in Sect. 2.2 and shown in Fig. 1 we could identify different flow directions that occurred 25 during our measurement period. When air masses came from easterly directions, particles were much more CCN active than during the rest of the campaign $\left(\kappa_{\mathrm{a}}\right.$ of 0.42 compared to 0.27 , Table 2 and Fig. 4). This increase in $\kappa_{\mathrm{a}}$ can be explained by large sulfate mass concentrations (Fig. 7a) coming probably from the densely populated and

\section{ACPD}

13, 32575-32624, 2013

CCN at the

Jungfraujoch

D. Rose et al.

Title Page

Abstract

Introduction

Conclusions

References

Tables

Figures

14

$\Delta$

4

Back

Full Screen / Esc

Printer-friendly Version

Interactive Discussion 
highly industrialized Po Valley resulting in a high inorganic mass fraction (up to $80 \%$, Fig. 7b). The higher hygroscopicity was particularly evident for the Aitken mode particles (50\% larger $\kappa_{\mathrm{a}}$ than for Aitken particles during the rest of the campaign). Moreover, the maximum activated fraction at $S=0.079 \%$ was significantly reduced during 5 the easterly air masses (on average MAF $=0.9$ ) indicating that there was a substantial fraction (10\%) of particles that could not be activated as cloud droplets. The same feature has been reported earlier (Rose et al., 2011; Gunthe et al., 2011) and can be explained by a significant fraction of relatively fresh externally mixed weakly $\mathrm{CCN}$-active soot particles with effective hygroscopicity parameters around $\kappa_{\mathrm{a}}=0.01$. On the other 10 hand, the particles that were CCN active at this supersaturation (particle diameter of $\sim 160 \mathrm{~nm})$ were more homogeneously mixed $\left(\sigma_{\mathrm{a}} / D_{\mathrm{a}}=0.06\right)$ than during the rest of the campaign $\left(\sigma_{\mathrm{a}} / D_{\mathrm{a}} \approx 0.09\right)$.

\subsection{Dependence of particle hygroscopicity on chemical composition}

Figure 8 shows the correlation of the hygroscopicity parameter $k_{\mathrm{a}}$ with the organic 15 mass fraction $f_{\text {org }}$ for all times when both CCN and AMS data were available. Note that the individual $f_{\text {org }}$ data points were calculated from the total mass concentrations over the size range of $D_{\mathrm{va}}=40-1000 \mathrm{~nm}$ (Sect. 2.3.3). As already shown in Fig. 7b, the organic mass fractions varied between $\sim 0.2$ (minimum on 12 March) and almost 1.0 (maximum on $7 \mathrm{March}$ ) with an average of 0.43 over the investigated time. As ex$\left(R^{2}=0.5\right)$ we could find for $\kappa_{\mathrm{a}}$ values observed at the smallest supersaturation level, which corresponds to the largest particle size range. The correlation deteriorated with increasing supersaturation, i.e., with decreasing size of the investigated particles. We expected this result as larger particles contribute more to the total mass than smaller ones do and therefore the measured bulk chemical composition is more representative for the larger diameters. When extrapolating the linear least squares fit line in Fig. $8 \mathrm{a}$ to $f_{\text {org }}=0$, we obtained $\kappa_{\text {inorg }}=0.63$ for the hygroscopicity of the inorganic fraction, which
ACPD

13, 32575-32624, 2013

$\mathrm{CCN}$ at the

Jungfraujoch

D. Rose et al.

Title Page

Abstract

Introduction

Conclusions

References

Tables

Figures

14

$\rightarrow 1$

4

Back

Close

Full Screen / Esc

Printer-friendly Version

Interactive Discussion 
is characteristic for ammonium sulfate and related compounds (Petters and Kreidenweis, 2007). Extrapolation to $f_{\text {org }}=1$, yielded $k_{\text {org }}=0.18$ for the hygroscopicity of the organic fraction. The values for $\kappa_{\text {org }}$ and $\kappa_{\text {inorg }}$ became smaller for the larger supersaturation levels. Similar values for $\kappa_{\text {inorg }}$ have been also derived from other recent studies 5 comparing AMS with CCN measurements (e.g., Gunthe et al., 2009, 2011; Rose et al., 2011; Dusek et al., 2010; King et al., 2009; Shinozuka et al., 2009; Roberts et al., 2010; Jimenez et al., 2009; Duplissy et al., 2011; Sjogren et al., 2008), while $\kappa_{\text {org }}$ is slightly higher. This is likely due to longer aging and higher oxygenation of the particulate organic matter sampled in free tropospheric air at the Jungfraujoch compared to 10 the boundary layer air sampled in the preceding studies in rainforest (Gunthe et al., 2009) and megacity environments (Rose et al., 2011; Gunthe et al., 2011).

In analogy to Gunthe et al. $(2009,2011)$ and Rose et al. $(2011), \kappa_{\text {org }}$ and $\kappa_{\text {inorg }}$ can be inserted in a simple mixing rule: $\kappa_{\mathrm{p}}=\kappa_{\text {inorg }} \cdot f_{\text {inorg }}+\kappa_{\text {org }} \cdot f_{\text {org }}$ to predict the size and time dependence of aerosol hygroscopicity based on the inorganic and organic mass 15 fractions determined by AMS. Figure 4 displays $\kappa_{\mathrm{p}}$ as calculated from the campaign mean size distribution of organic and inorganic mass fractions (Fig. 5b). It shows an increase of particle hygroscopicity with increasing size and reproduces the campaign average of size dependent $\kappa_{\mathrm{a}}$ quite well. Figure 6a displays the time series of $\kappa_{\mathrm{p}}$, which was calculated from the organic and inorganic mass fractions integrated over the entire particle size-range of AMS measurements (Fig. 7b). In Fig. $6 a$ is shown that $k_{\mathrm{p}}$ followed the temporal evolution of $\kappa_{\mathrm{a}}$ at $S=0.079 \%$ quite well for most of the time during the campaign. This result was expected since already $f_{\text {org }}$ correlated best with $\kappa_{\mathrm{a}}$ observed for the lowest supersaturation level ( $S=0.079 \%$, Fig. 8).

Note that the standard ZSR mixing rule for volume based hygroscopicity parameters would require the use of volume rather than mass fractions. For simplicity, however, we refrain from making assumptions on particle density here as these introduce additional uncertainties but do not improve the correlation. This has already been discussed by Gunthe et al. (2009) and Mikhailov et al. (2013) and will be further addressed in followup studies.

\section{ACPD}

13, 32575-32624, 2013

$\mathrm{CCN}$ at the

Jungfraujoch

D. Rose et al.

Title Page

Abstract

Introduction

Conclusions

References

Tables

Figures

14

$>1$

4

Back

Close

Full Screen / Esc

Printer-friendly Version

Interactive Discussion 


\subsection{Precipitation event}

As evident from Fig. 6b, the aerosol and CCN properties during the night of 9/10 March seemed to be exceptionally different from the rest of the time. For a more detailed investigation of this event, Fig. 9 shows the temporal evolution of selected aerosol and CCN parameters at $S=0.66 \%$ between 9 March 21:00 LT and 10 March 12:00 LT.

In the late evening of 9 March, the total particle number concentration at $S=0.66 \%$ was very high (up to $\sim 1400 \mathrm{~cm}^{-3}$, which is 3-4 times higher than the campaign average value; Fig. 9a), and the particle size distribution exhibited two modes, an Aitken mode with a maximum around $\sim 80 \mathrm{~nm}$, and an accumulation mode with a maximum around $\sim 200 \mathrm{~nm}$ (Fig. 9b). At 22:46 LT, the CCN efficiency spectrum at $S=0.66 \%$ reached from zero to MAF $=0.91$ (Fig. 9d), which is considerably lower than typical at this supersaturation $\left(\mathrm{MAF}_{\mathrm{f}} \approx 1\right)$. The activation diameter $(\sim 70 \mathrm{~nm})$ was larger than the campaign average $(\sim 50 \mathrm{~nm})$, i.e., particles in this size range were less hygroscopic than on average $\left(\kappa_{\mathrm{a}} \approx 0.1 \mathrm{vs}\right.$. average $\left.\kappa_{\mathrm{a}} \approx 0.23\right)$. About $60 \%$ of all particles were CCN15 active at $S=0.66 \%$, which is also similar to the value obtained for the entire campaign $\left(N_{\mathrm{CCN}, \text { tot, } \mathrm{m}} / N_{\mathrm{CN}, \text { tot }}=0.60\right)$.

Shortly after midnight, the total particle number concentration suddenly dropped down to $\sim 470 \mathrm{~cm}^{-3}$ (at 01:21 LT) because the accumulation mode disappeared almost completely. Only $\sim 20 \%$ of all particles $\left(N_{\mathrm{CN} \text {,tot }}\right)$ were still CCN-active at $S=0.66 \%$.

20 The CCN efficiency spectrum reached only up to half of unity (i.e., MAF $=0.48$ ), which means that $\sim 50 \%$ of the particles of $110 \mathrm{~nm}$ in diameter were CCN-inactive even at this high level of supersaturation, i.e., they had a $k$ of $\leq 0.03$. As shown by Rose et al. (2011) it can be assumed that this fraction of CCN-inactive particles consisted of externally mixed weakly $\mathrm{CCN}$-active soot particles with very low hygroscopicity. In a polluted 25 megacity region in China, Rose et al. (2011) also observed a large fraction of these particles (up to $60 \%$ ) but only at low supersaturations $(\leq 0.27 \%$ ). At $S=0.66 \%$, those particles were already activated indicating that the particles we observed here at the JFJ must have been even less hygroscopic. A possible explanation of this event (rapidly

\section{ACPD}

13, 32575-32624, 2013

$\mathrm{CCN}$ at the

Jungfraujoch

D. Rose et al.

Title Page

Abstract

Introduction

Conclusions

References

Tables

Figures

14

$\Delta$

4

Back

Full Screen / Esc

Printer-friendly Version

Interactive Discussion 
decreasing particle concentration together with increasing fraction of $\mathrm{CCN}$-inactive particles) could be that most of the accumulation mode particles we observed at 22:46 LT on 9 March were activated as cloud droplets, precipitated and were thus removed from the sampled air we measured at 01:21 LT on 10 March.

5 If we calculate the absolute number concentration of particles in the $110 \mathrm{~nm}$ size bin that are CCN-inactive at $S=0.66 \%$, we obtain a value of $116 \mathrm{~cm}^{-3}$ at $22: 46 \mathrm{LT}$ $\left(\sim 10 \%\right.$ of $\left.1160 \mathrm{~cm}^{-3}\right)$ and an almost equal value of $135 \mathrm{~cm}^{-3}$ at $01: 21 \mathrm{LT}(\sim 50 \%$ of $\sim 270 \mathrm{~cm}^{-3}$ ). Figure A3 shows the number size distribution of particles that are $\mathrm{CCN}$ inactive at $S=0.66 \%$. As can be seen, indeed the whole size distribution of inactive 10 particles at 22:46 LT and 01:21 LT are similar to each other. This supports the argument that the change of CCN properties was not caused, e.g., by a different air mass, but that the CCN-active particles were activated, grew to cloud droplets and were then removed by precipitation, whereas the $\mathrm{CCN}$-inactive particles remained unaffected by the precipitation formation.

15 Until 4 a.m. the particle concentration in the Aitken mode decreased even more leading to a total CN number concentration of $\sim 350 \mathrm{~cm}^{-3}$ (Fig. 9a). MAF increased very little and the hygroscopicity of the CCN-active particles $\left(\kappa_{\mathrm{a}}\right)$ became slightly higher $(\sim 0.2)$ (Fig. 9e). The total CCN efficiency remained very low at $\sim 0.2-0.3$ (Fig. 9a).

Until noon of 10 March the aerosol and CCN properties reached their campaign

average behavior again (cf. Table 2): the total CN number concentration was around $380 \mathrm{~cm}^{-3}$, the total CCN efficiency reached $\sim 0.6$ again, and the CCN efficiency spectra went up to $\mathrm{MAF}_{\mathrm{f}} \approx 1$ ). The particle hygroscopicity exhibited a value of $k_{\mathrm{a}} \approx 0.3$, which was even a little bit higher than the average value at this supersaturation. The number concentration of $\mathrm{CCN}$-inactive particles, however, decreased and the peak of their number size distribution shifted towards smaller diameters (Fig. A3).

Summarizing, the evolution of the parameters shown in Fig. 9 presents an example of the development of $\mathrm{CCN}$ properties during a cloud and precipitation event: most of the accumulation particles (here $\sim 85 \%$ ) and a part of the Aitken particles (here $\sim 30 \%$ ) are activated into cloud droplets. Even if they are not very hygroscopic like in this case

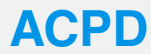

13, 32575-32624, 2013

CCN at the

Jungfraujoch

D. Rose et al.

Title Page

Abstract

Introduction

Conclusions

References

Tables

Figures

14

$\rightarrow 1$

4

Back

$>$

Close

Full Screen / Esc

Printer-friendly Version

Interactive Discussion 
they are $\mathrm{CCN}$-active because of their size (Kelvin effect). Through precipitation they are removed from the air, so that only those particles remain that have a significantly lower than average hygroscopicity (i.e., externally mixed weakly CCN-active soot particles) or that have an activation diameter that is smaller than the critical activation diameter particles would have at the ambient supersaturation present in the cloud. The remaining "clean" air (mostly consisting of particles that were CCN-inactive before) will then age by condensation of precursor gases onto the existing particles, coagulation, or chemical transformation, thus resulting in increasing number concentration of accumulation particles, increasing fraction of $\mathrm{CCN}$-active particles and increasing particle 10 hygroscopicity in general.

\section{Summary and conclusions}

As part of the CLACE-6 campaign we performed size-resolved CCN measurements at the high-alpine research station Jungfraujoch in March 2007. The dry activation diameters measured at $S=0.079 \%$ to $S=0.66 \%$ were in the range of $\sim 200$ to $40 \mathrm{~nm}$ and the effective hygroscopicity parameters $\kappa_{\mathrm{a}}$ varied in the range of $\sim 0.1$ to 0.6 . The mean value of $\kappa_{\mathrm{a}}$ characterizing the hygroscopicity of all aerosol particles averaged over the whole campaign and investigated size range was 0.3 , which is slightly higher than the average particle hygroscopicity observed during a 17 month period at the JFJ by Jurányi et al. (2011). It is similar to the average hygroscopicity inferred for other continental locations (e.g. Rose et al., 2010, 2011; Chang et al., 2010; Shinozuka et al., 2009; Andreae and Rosenfeld, 2008; Pöschl et al., 2009; Pringle et al., 2010). Particles in the Aitken size range were on average less hygroscopic $(0.23-0.30)$ than particles in the accumulation size range (0.32-0.43). During a two-day period, when air masses came from easterly directions crossing the Po Valley in Italy, the particles were much

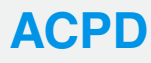

13, 32575-32624, 2013

CCN at the

Jungfraujoch

D. Rose et al.

Title Page

Abstract

Introduction

Conclusions

References

Tables

Figures

14

$\rightarrow 1$

4

Back

Full Screen / Esc

Printer-friendly Version

Interactive Discussion in $\kappa_{a}$ could be explained by large inorganic mass fractions probably due to sulfate or 
$\mathrm{SO}_{2}$ emissions from the densely populated and highly industrialized area of the Po Valley.

The observed total $\mathrm{CN}$ and $\mathrm{CCN}$ concentrations $\left(N_{\mathrm{CN}, \text { tot }} \approx 400 \mathrm{~cm}^{-3} ; N_{\mathrm{CCN}, \text { tot,m }} \approx\right.$ $50-250 \mathrm{~cm}^{-3}$ for $S=0.079-0.66 \%$ ) are similar to other measurements at the JFJ (Ju5 rányi et al., 2011). They are about the same as in other remote clean regions (e.g., Amazon Basin), and about one to two orders of magnitude smaller than in polluted regions (e.g., European and Chinese megacities, respectively). Diurnal cycles could not be observed for any CCN parameter due to the lack of periodical injections from the PBL, which is typical for this high altitude site at winter time.

10 Particle mass concentrations measured with an AMS in the size range of $D_{\text {va }}=40$ $1000 \mathrm{~nm}$ were on average $\sim 0.5 \mathrm{\mu gm}^{-3}$. The time series of the derived organic mass fraction $\left(f_{\text {org }}\right)$ correlated well with the $\kappa_{\mathrm{a}}$ values obtained at $S=0.079 \%: \kappa_{\mathrm{a}}$ decreased with increasing $f_{\text {org }}$. Extrapolation of the linear correlation between $\kappa_{\mathrm{a}}$ and $f_{\text {org }}$ yielded $\kappa_{\text {org }}=0.18$ and $\kappa_{\text {inorg }}=0.63$ for the hygroscopicity of the organic and inorganic com-

15 ponents, respectively. The value for $\kappa_{\text {inorg }}$ is in accordance with earlier studies relating $\kappa_{\mathrm{a}}$ to AMS derived mass fractions (e.g. Rose et al., 2011; Gunthe et al., 2011, 2009), while $\kappa_{\text {org }}$ is slightly higher. This is likely due to longer aging and higher oxygenation of the particulate organic matter sampled in the free tropospheric air sampled at the Jungfraujoch compared to the boundary layer air sampled in the preceding studies in 20 rainforest (Gunthe et al., 2009) and megacity environments (Rose et al., 2011; Gunthe et al., 2011). The average size distribution of organic and inorganic mass fractions as obtained from AMS data showed higher proportions of inorganic matter with increasing particle size, which correlated well with the observed increased hygroscopicity of the aerosol particles.

25 In the night of 9/10 March we observed a precipitation event at the JFJ site. Our aerosol and CCN measurements showed that almost all accumulation mode particles and a part of the Aitken mode particles were activated as cloud droplets and then removed from the air by precipitation. The number concentration of externally mixed weakly $\mathrm{CCN}$-active soot particles remained constant before and after precipitation,

\section{ACPD}

13, 32575-32624, 2013

CCN at the

Jungfraujoch

D. Rose et al.

Title Page

Abstract

Introduction

Conclusions

References

Tables

Figures

14

$\Delta$

4

Back

Full Screen / Esc

Printer-friendly Version

Interactive Discussion 
which confirms that neither they were activated to cloud droplets nor they were washed out by the precipitation.

During the CLACE- 6 campaign we had the opportunity to directly compare two DMT CCN instruments for a certain time. When they both measured in polydisperse mode, 5 i.e., directly determining the total $\mathrm{CCN}$ number concentration, the results agreed very well ( $\sim 6 \%$ deviation) as long as the effective supersaturation was similar. Big differences in the supersaturation of the two instruments (e.g., $20 \%$ ), however, led to enormous differences in $N_{\mathrm{CCN} \text {,tot,p }}$ (e.g., $50 \%$ ), which emphasizes that it is extremely important to carefully calibrate the supersaturation of the instrument, especially at low $S$.

10 When one CCNC was operated in polydisperse mode and the other one measuring size-resolved activated fractions from which the total CCN concentration can be calculated, the differences in the total CCN concentration were on average 20 to $25 \%$. This inconsistency can be most likely attributed to a long sampling line and the inappropriate correction for diffusional losses.

15 Therefore we conclude that monodisperse CCN measurements are better for determining the hygroscopicity parameter accurately (additionally providing information on the mixing state), whereas they are less suitable for the measurement of total CCN concentrations, as the uncertainty is increased by the uncertainty of the SMPS measurement (Jurányi et al., 2013). Polydisperse CCN measurements, in contrast, provide more accurate total CCN concentrations, whereas inferred hygroscopicity parameters are tainted by the additional uncertainty of the SMPS.

Acknowledgements. Many thanks to all CLACE-6 team members for collaboration and help during the campaign. We gratefully acknowledge support by the Max Planck Society (MPG), MeteoSwiss within the framework of the Global Atmosphere Watch (GAW) program, 25 the International Foundation High Altitude Research Stations Jungfraujoch and Gornergart (HFSJG), and the German Research Foundation (DFG, SFB 641 TROPICE). Support by the project European Supersites for Atmospheric Aerosol Research (EUSAAR) and the FP6 Network Of Excellence ACCENT (access to infrastructures, field stations) is acknowledged as well as Meteo Swiss for providing meteorological data. We thank M. O. Andreae, and E. 30 Weingartner for support.

\section{ACPD}

13, 32575-32624, 2013

CCN at the

Jungfraujoch

D. Rose et al.

Title Page

Abstract

Introduction

Conclusions

References

Tables

Figures

14

$\Delta$

4

Back

Full Screen / Esc

Printer-friendly Version

Interactive Discussion 
The service charges for this open access publication

have been covered by the Max Planck Society.

\section{ACPD}

13, 32575-32624, 2013

\section{References}

5 Andreae, M. O. and Rosenfeld, D.: Aerosol-cloud-precipitation interactions. Part 1. The nature and sources of cloud-active aerosols, Earth Sci. Rev., 89, 13-41, 2008. 32591, 32597

Baltensperger, U., Gäggeler, H., Jost, D., Lugauer, M., Schwikowski, M., Weingartner, E., and Seibert, P.: Aerosol climatology at the high-alpine site Jungfraujoch, Switzerland, J. Geophys. Res., 102, 19707-19715, 1997. 32580

10 Bougiatioti, A., Nenes, A., Fountoukis, C., Kalivitis, N., Pandis, S. N., and Mihalopoulos, N.: Size-resolved CCN distributions and activation kinetics of aged continental and marine aerosol, Atmos. Chem. Phys., 11, 8791-8808, doi:10.5194/acp-11-8791-2011, 2011. 32578

Bukowiecki, N., Zieger, P., Weingartner, E., Jurányi, Z., Gysel, M., Neininger, B., Schneider, B., Hueglin, C., Ulrich, A., Wichser, A., Henne, S., Brunner, D., Kaegi, R., Schwikowski, M., Tobler, L., Wienhold, F. G., Engel, I., Buchmann, B., Peter, T., and Baltensperger, U.: Groundbased and airborne in-situ measurements of the Eyjafjallajökull volcanic aerosol plume in Switzerland in spring 2010, Atmos. Chem. Phys., 11, 10011-10030, doi:10.5194/acp-1110011-2011, 2011. 32578, 32591

Canagaratna, M. R., Jayne, J. T., Jimenez, J. L., Allan, J. D., Alfarra, M. R., Zhang, Q., Onasch, T. B., Drewnick, F., Coe, H., Middlebrook, A., Delia, A., Williams, L. R., Trimborn, A. M., Northway, M. J., DeCarlo, P. F., Kolb, C. E., Davidovits, P., and Worsnop, D. R.: Chemical and microphysical characterization of ambient aerosols with the aerodyne aerosol mass spectrometer, Mass Spectrom. Rev., 26, 185-222, 2007. 32586

Cerully, K. M., Raatikainen, T., Lance, S., Tkacik, D., Tiitta, P., Petäjä, T., Ehn, M., Kulmala, M., Worsnop, D. R., Laaksonen, A., Smith, J. N., and Nenes, A.: Aerosol hygroscopicity and CCN activation kinetics in a boreal forest environment during the 2007 EUCAARI campaign, Atmos. Chem. Phys., 11, 12369-12386, doi:10.5194/acp-11-12369-2011, 2011. 32578

Chang, R. Y.-W., Slowik, J. G., Shantz, N. C., Vlasenko, A., Liggio, J., Sjostedt, S. J., Leaitch, W. R., and Abbatt, J. P. D.: The hygroscopicity parameter $(k)$ of ambient organic aerosol at a field site subject to biogenic and anthropogenic influences: relationship to degree

\section{$\mathrm{CCN}$ at the \\ Jungfraujoch}

D. Rose et al.

Title Page

Abstract

Introduction

Conclusions

References

Tables

Figures

14

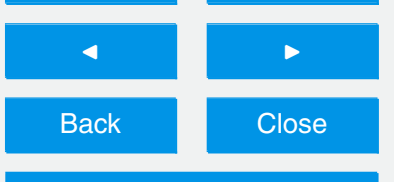

Full Screen / Esc

Printer-friendly Version

Interactive Discussion 
of aerosol oxidation, Atmos. Chem. Phys., 10, 5047-5064, doi:10.5194/acp-10-5047-2010, 2010. 32591, 32597

Collaud Coen, M., Weingartner, E., Nyeki, S., Cozic, J., Henning, S., Verheggen, B., Gehrig, R., and Baltensperger, U.: Long-term trend analysis of aerosol variables at the high-alpine site

5 Jungfraujoch, J. Geophys. Res., 112, D13213, doi:10.1029/2006JD007995, 2007. 32580

Collaud Coen, M., Weingartner, E., Furger, M., Nyeki, S., Prévôt, A. S. H., Steinbacher, M., and Baltensperger, U.: Aerosol climatology and planetary boundary influence at the Jungfraujoch analyzed by synoptic weather types, Atmos. Chem. Phys., 11, 5931-5944, doi:10.5194/acp11-5931-2011, 2011. 32579, 32580, 32592

10 Cozic, J., Verheggen, B., Mertes, S., Connolly, P., Bower, K., Petzold, A., Baltensperger, U., and Weingartner, E.: Scavenging of black carbon in mixed phase clouds at the high alpine site Jungfraujoch, Atmos. Chem. Phys., 7, 1797-1807, doi:10.5194/acp-7-1797-2007, 2007. 32579,32587

Cozic, J., Verheggen, B., Weingartner, E., Crosier, J., Bower, K. N., Flynn, M., Coe, H., Henning, S., Steinbacher, M., Henne, S., Collaud Coen, M., Petzold, A., and Baltensperger, U.: Chemical composition of free tropospheric aerosol for PM1 and coarse mode at the high alpine site Jungfraujoch, Atmos. Chem. Phys., 8, 407-423, doi:10.5194/acp-8-407-2008, 2008. 32580, 32587

Cziczo, D. J., Stetzer, O., Worringen, A., Ebert, M., Weinbruch, S., Kamphus, M., Gallavardin, S. J., Curtius, J., Borrmann, S., Froyd, K. D., Mertes, S., Möhler, O., and Lohmann, U.: Inadvertent climate modification due to anthropogenic lead, Nat. Geosci., 2, 333-336, doi:10.1038/ngeo499, 2009. 32587

DeCarlo, P. F., Slowik, J. G., Worsnop, D. R., Davidovits, P., and Jimenez, J. L.: Particle morphology and density characterization by combined mobility and aerodynamic diameter measurements. Part 1: Theory, Aerosol Sci. Tech., 38, 1185-1205, doi:10.1080/027868290903907, 2004. 32586

DeCarlo, P. F., Kimmel, J. R., Trimborn, A., Northway, M. J., Jayne, J. T., Aiken, A. C., Gonin, M., Fuhrer, K., Horvath, T., Docherty, K. S., Worsnop, D. R., and Jimenez, J. L.: Field-deployable, high-resolution, time-of-flight aerosol mass spectrometer, Anal. Chem., 78, $30 \quad 8281-8289,2006.32586$

Deng, Z. Z., Zhao, C. S., Ma, N., Liu, P. F., Ran, L., Xu, W. Y., Chen, J., Liang, Z., Liang, S., Huang, M. Y., Ma, X. C., Zhang, Q., Quan, J. N., Yan, P., Henning, S., Mildenberger, K., Sommerhage, E., Schäfer, M., Stratmann, F., and Wiedensohler, A.: Size-resolved and bulk

\section{ACPD}

13, 32575-32624, 2013

\section{$\mathrm{CCN}$ at the \\ Jungfraujoch}

D. Rose et al.

Title Page

Abstract

Introduction

Conclusions

References

Tables

Figures

14

$\rightarrow 1$

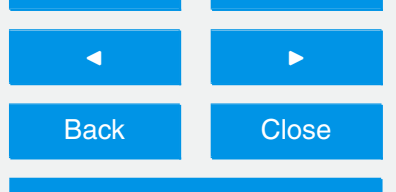

Full Screen / Esc

Printer-friendly Version

Interactive Discussion

\section{1}


activation properties of aerosols in the North China Plain, Atmos. Chem. Phys., 11, 38353846, doi:10.5194/acp-11-3835-2011, 2011. 32578, 32589

Deng, Z. Z., Zhao, C. S., Ma, N., Ran, L., Zhou, G. Q., Lu, D. R., and Zhou, X. J.: An examination of parameterizations for the CCN number concentration based on in situ measurements of aerosol activation properties in the North China Plain, Atmos. Chem. Phys., 13, 6227-6237, doi:10.5194/acp-13-6227-2013, 2013. 32578

Duplissy, J., DeCarlo, P. F., Dommen, J., Alfarra, M. R., Metzger, A., Barmpadimos, I., Prevot, A. S. H., Weingartner, E., Tritscher, T., Gysel, M., Aiken, A. C., Jimenez, J. L., Canagaratna, M. R., Worsnop, D. R., Collins, D. R., Tomlinson, J., and Baltensperger, U.: Relating hygroscopicity and composition of organic aerosol particulate matter, Atmos. Chem. Phys., 11, 1155-1165, doi:10.5194/acp-11-1155-2011, 2011. 32594

Dusek, U., Frank, G. P., Hildebrandt, L., Curtius, J., Schneider, J., Walter, S., Chand, D., Drewnick, F., Hings, S., Jung, D., Borrmann, S., and Andreae, M. O.: Size matters more than chemistry for cloud nucleating ability of aerosol particles, Science, 312, 1375-1378, 2006. 32578

Dusek, U., Frank, G. P., Curtius, J., Drewnick, F., Schneider, J., Kürten, A., Rose, D., Andreae, M. O., Borrmann, S., and Pöschl, U.: Enhanced organic mass fraction and decreased hygroscopicity of cloud condensation nuclei (CCN) during new particle formation events, Geophys. Res. Lett., 37, L03804, doi:10.1029/2009GL040930, 2010. 32578, 32594

20

Ebert, M., Worringen, A., Benker, N., Mertes, S., Weingartner, E., and Weinbruch, S.: Chemical composition and mixing-state of ice residuals sampled within mixed phase clouds, Atmos. Chem. Phys., 11, 2805-2816, doi:10.5194/acp-11-2805-2011, 2011. 32587

Frank, G. P., Dusek, U., and Andreae, M. O.: Technical note: A method for measuring size-resolved CCN in the atmosphere, Atmos. Chem. Phys. Discuss., 6, 4879-4895, doi:10.5194/acpd-6-4879-2006, 2006. 32582

Gunthe, S. S., King, S. M., Rose, D., Chen, Q., Roldin, P., Farmer, D. K., Jimenez, J. L., Artaxo, P., Andreae, M. O., Martin, S. T., and Pöschl, U.: Cloud condensation nuclei in pristine tropical rainforest air of Amazonia: size-resolved measurements and modeling of atmospheric aerosol composition and CCN activity, Atmos. Chem. Phys., 9, 7551-7575, doi:10.5194/acp-9-7551-2009, 2009. 32578, 32590, 32594, 32598

Gunthe, S. S., Rose, D., Su, H., Garland, R. M., Achtert, P., Nowak, A., Wiedensohler, A., Kuwata, M., Takegawa, N., Kondo, Y., Hu, M., Shao, M., Zhu, T., Andreae, M. O., and Pöschl, U.: Cloud condensation nuclei (CCN) from fresh and aged air pollution in the megac-

\section{ACPD}

13, 32575-32624, 2013

$\mathrm{CCN}$ at the

Jungfraujoch

D. Rose et al.

Title Page

Abstract

Introduction

Conclusions

References

Tables

Figures

14

$\Delta$

4

Back

$\triangleright$

Close

Full Screen / Esc

Printer-friendly Version

Interactive Discussion 
ity region of Beijing, Atmos. Chem. Phys., 11, 11023-11039, doi:10.5194/acp-11-110232011, 2011. 32578, 32585, 32590, 32591, 32593, 32594, 32598

Hammer, E., Bukowiecki, N., Gysel, M., Jurányi, Z., Hoyle, C. R., Vogt, R., Baltensperger, U., and Weingartner, E.: Investigation of the effective peak supersaturation for liquid-phase $5 \quad$ clouds at the high-alpine site Jungfraujoch, Switzerland (3580 ma.s.l.), Atmos. Chem. Phys. Discuss., 13, 20419-20462, doi:10.5194/acpd-13-20419-2013, 2013. 32579

Henning, S., Weingartner, E., Schmidt, S., Wendisch, M., Gäggeler, H. W., and Baltensperger, U.: Size-dependent aerosol activation at the high-alpine site Jungfraujoch (3580 m a.s.l.), Tellus B, 54, 82-95, 2002. 32579

10 Henning, S., Weingartner, E., Schwikowski, M., Gäggeler, H. W., Gehrig, R., Hinz, K.-P., Trimborn, A., Spengler, B., and Baltensperger, U.: Seasonal variation of water-soluble ions of the aerosol at the high-alpine site Jungfraujoch (3580 m a.s.l.), J. Geophys. Res., 108, 4030, doi:10.1029/2002JD002439, 2003. 32587

Hong, J., Häkkinen, S. A. K., Paramonov, M., Äijälä, M., Hakala, J., Nieminen, T., Mikkilä, J., Prisle, N., Kulmala, M., Riipinen, I., Bilde, M., Kerminen, V.-M., and Petäjä, T.: Hygroscopicity, CCN and volatility properties of submicron atmospheric aerosol in a boreal forest environment during the summer of 2010, Atmos. Chem. Phys. Discuss., 13, 29097-29136, doi:10.5194/acpd-13-29097-2013, 2013. 32578

IPCC: Climate Change 2007: The Physical Science Basis, Contribution of Working Group I to the Fourth Assessment Report of the Intergovernmental Panel on Climate Change, Cambridge University Press, Cambridge and New York, 996 pp., 2007. 32578

Irwin, M., Robinson, N., Allan, J. D., Coe, H., and McFiggans, G.: Size-resolved aerosol water uptake and cloud condensation nuclei measurements as measured above a Southeast Asian rainforest during OP3, Atmos. Chem. Phys., 11, 11157-11174, doi:10.5194/acp-11-111572011, 2011. 32578

Jimenez, J. L., Canagaratna, M. R., Donahue, N. M., Prevot, A. S. H., Zhang, Q., Kroll, J. H., DeCarlo, P. F., Allan, J. D., Coe, H., Ng, N. L., Aiken, A. C., Docherty, K. S., Ulbrich, I. M., Grieshop, A. P., Robinson, A. L., Duplissy, J., Smith, J. D., Wilson, K. R., Lanz, V. A., Hueglin, C., Sun, Y. L., Tian, J., Laaksonen, A., Raatikainen, T., Rautiainen, J., Vaattovaara, P., Ehn, M., Kulmala, M., Tomlinson, J. M., Collins, D. R., Cubison, M. J., Dunlea, E. J., Huffman, J. A., Onasch, T. B., Alfarra, M. R., Williams, P. I., Bower, K., Kondo, Y., Schneider, J., Drewnick, F., Borrmann, S., Weimer, S., Demerjian, K., Salcedo, D., Cottrell, L., Griffin, R., Takami, A., Miyoshi, T., Hatakeyama, S., Shimono, A., Sun, J. Y., Zhang, Y. M.,

\section{ACPD}

13, 32575-32624, 2013

CCN at the
Jungfraujoch

D. Rose et al.

Title Page

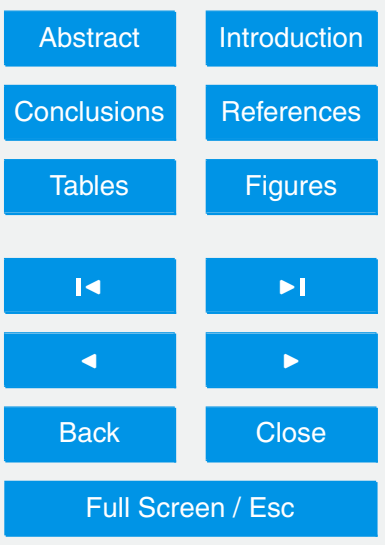

Printer-friendly Version

Interactive Discussion 
Dzepina, K., Kimmel, J. R., Sueper, D., Jayne, J. T., Herndon, S. C., Trimborn, A. M., Williams, L. R., Wood, E. C., Middlebrook, A. M., Kolb, C. E., Baltensperger, U., and Worsnop, D. R.: Evolution of organic aerosols in the atmosphere, Science, 326, 1525-1529, doi:10.1126/science.1180353, 2009. 32594

5 Jurányi, Z., Gysel, M., Weingartner, E., DeCarlo, P. F., Kammermann, L., and Baltensperger, U.: Measured and modelled cloud condensation nuclei number concentration at the high alpine site Jungfraujoch, Atmos. Chem. Phys., 10, 7891-7906, doi:10.5194/acp-10-7891-2010, 2010. 32579, 32588, 32590

Jurányi, Z., Gysel, M., Weingartner, E., Bukowiecki, N., Kammermann, L., and Baltensperger, U.: A 17 month climatology of the cloud condensation nuclei number concentration at the high alpine site Jungfraujoch, J. Geophys. Res., 116, D10204, doi:10.1029/2010JD015199, 2011. 32579, 32590, 32591, 32597, 32598

Jurányi, Z., Tritscher, T., Gysel, M., Laborde, M., Gomes, L., Roberts, G., Baltensperger, U., and Weingartner, E.: Hygroscopic mixing state of urban aerosol derived from size-resolved cloud condensation nuclei measurements during the MEGAPOLI campaign in Paris, Atmos. Chem. Phys., 13, 6431-6446, doi:10.5194/acp-13-6431-2013, 2013. 32578, 32589, 32590, 32599

Kammermann, L., Gysel, M., Weingartner, E., and Baltensperger, U.: 13-month climatology of the aerosol hygroscopicity at the free tropospheric site Jungfraujoch (3580 ma.s.l.), Atmos.

$20 \quad$ Chem. Phys., 10, 10717-10732, doi:10.5194/acp-10-10717-2010, 2010. 32579

Kamphus, M., Ettner-Mahl, M., Klimach, T., Drewnick, F., Keller, L., Cziczo, D. J., Mertes, S., Borrmann, S., and Curtius, J.: Chemical composition of ambient aerosol, ice residues and cloud droplet residues in mixed-phase clouds: single particle analysis during the Cloud and Aerosol Characterization Experiment (CLACE 6), Atmos. Chem. Phys., 10, 8077-8095, doi:10.5194/acp-10-8077-2010, 2010. 32587

Kim, J. H., Yum, S. S., Shim, S., Yoon, S.-C., Hudson, J. G., Park, J., and Lee, S.-J.: On aerosol hygroscopicity, cloud condensation nuclei (CCN) spectra and critical supersaturation measured at two remote islands of Korea between 2006 and 2009, Atmos. Chem. Phys., 11, 12627-12645, doi:10.5194/acp-11-12627-2011, 2011. 32578

30 King, S. M., Rosenoern, T., Shilling, J. E., Chen, Q., and Martin, S. T.: Increased cloud activation potential of secondary organic aerosol for atmospheric mass loadings, Atmos. Chem. Phys., 9, 2959-2971, doi:10.5194/acp-9-2959-2009, 2009. 32594
ACPD

13, 32575-32624, 2013

CCN at the

Jungfraujoch

D. Rose et al.

Title Page

Abstract

Introduction

Conclusions

References

Tables

Figures

14

$\Delta$

4

Back

$>$

Close

Full Screen / Esc

Printer-friendly Version

Interactive Discussion 
Kreidenweis, S. M., Petters, M. D., and Chuang, P. Y.: Cloud particle precursors, in: Clouds in the Perturbed Climate System: their Relationship to Energy Balance, Atmospheric Dynamics, and Precipitation, edited by: Heintzenberg, J. and Charlson, R. J., Strüngmann Forum Report, vol. 2, MIT Press, Cambridge, MA, 2009. 32584

5 Kuwata, M. and Kondo, Y.: Dependence of size-resolved CCN spectra on the mixing state of nonvolatile cores observed in Tokyo, J. Geophys. Res., 113, D19202, doi:10.1029/2007JD009761, 2008. 32578

Kuwata, M., Kondo, Y., Mochida, M., Takegawa, N., and Kawamura, K.: Dependence of CCN activity of less volatile particles on the amount of coating observed in Tokyo, J. Geophys. Res., 112, D11207, doi:10.1029/2006JD007758, 2007. 32578

Kuwata, M., Kondo, Y., Miyazaki, Y., Komazaki, Y., Kim, J. H., Yum, S. S., Tanimoto, H., and Matsueda, H.: Cloud condensation nuclei activity at Jeju Island, Korea in spring 2005, Atmos. Chem. Phys., 8, 2933-2948, doi:10.5194/acp-8-2933-2008, 2008. 32578

Kuwata, M., Kondo, Y., and Takegawa, N.: Critical condensed mass for activation of black carbon as cloud condensation nuclei in Tokyo, J. Geophys. Res., 114, D20202, doi:10.1029/2009JD012086, 2009. 32578

Lance, S., Medina, J., Smith, J. N., and Nenes, A.: Mapping the operation of the DMT continuous flow CCN counter, Aerosol Sci. Tech., 40, 242-254, 2006. 32581

Lance, S., Raatikainen, T., Onasch, T. B., Worsnop, D. R., Yu, X.-Y., Alexander, M. L., Stolzenburg, M. R., McMurry, P. H., Smith, J. N., and Nenes, A.: Aerosol mixing state, hygroscopic growth and cloud activation efficiency during MIRAGE 2006, Atmos. Chem. Phys., 13, 50495062, doi:10.5194/acp-13-5049-2013, 2013. 32578

Liu, D., Flynn, M., Gysel, M., Targino, A., Crawford, I., Bower, K., Choularton, T., Jurányi, Z., Steinbacher, M., Hüglin, C., Curtius, J., Kampus, M., Petzold, A., Weingartner, E., Baltensperger, U., and Coe, $\mathrm{H}$.: Single particle characterization of black carbon aerosols at a tropospheric alpine site in Switzerland, Atmos. Chem. Phys., 10, 7389-7407, doi:10.5194/acp10-7389-2010, 2010. 32587

Lohmann, U. and Feichter, J.: Global indirect aerosol effects: a review, Atmos. Chem. Phys., 5, 715-737, doi:10.5194/acp-5-715-2005, 2005. 32578

30 Matthew, B. M., Middlebrook, A. M., and Onasch, T. B.: Collection efficiencies in an aerodyne aerosol mass spectrometer as a function of particles phase for laboratory generated aerosols, Aerosol Sci. Tech., 42, 884-898, doi:10.1080/02786820802356797, 2008. 32586

\section{ACPD}

13, 32575-32624, 2013

$\mathrm{CCN}$ at the

Jungfraujoch

D. Rose et al.

Title Page

Abstract

Introduction

Conclusions

References

Tables

Figures

14

$>1$

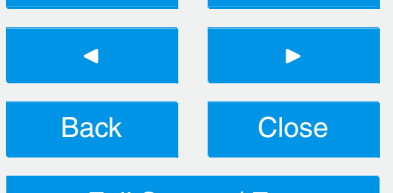

Full Screen / Esc

Printer-friendly Version

Interactive Discussion 
Mertes, S., Verheggen, B., Walter, S., Connolly, P., Ebert, M., Schneider, J., Bower, K. N., Cozic, J., Weinbruch, S., Baltensperger, U., and Weingartner, E.: Counterflow virtual impactor based collection of small ice particles in mixed-phase clouds for the physico-chemical characterization of tropospheric ice nuclei: sampler description and first case study, Aerosol Sci.

$5 \quad$ Tech., 41, 848-864, doi:10.1080/02786820701501881, 2007. 32581

Middlebrook, A. M., Bahreini, R., Jimenez, J. L., and Canagaratna, M. R.: Evaluation of composition-dependent collection efficiencies for the aerodyne aerosol mass spectrometer using field data, Aerosol Sci. Tech., 46, 258-271, doi:10.1080/02786826.2011.620041, 2012. 32586

10 Mikhailov, E., Vlasenko, S., Rose, D., and Pöschl, U.: Mass-based hygroscopicity parameter interaction model and measurement of atmospheric aerosol water uptake, Atmos. Chem. Phys., 13, 717-740, doi:10.5194/acp-13-717-2013, 2013. 32594

Moore, R. H., Nenes, A., and Medina, J.: Scanning mobility CCN analysis: a method for fast measurements of size-resolved CCN distributions and activation kinetics, Aerosol Sci. Tech., 44, 861-871, doi:10.1080/02786826.2010.498715, 2010. 32589

Nessler, R., Bukowiecki, N., Henning, S., Weingartner, E., Calpini, B., and Baltensperger, U.: Simultaneous dry and ambient measurements of aerosol size distributions at the Jungfraujoch, Tellus B, 55, 808-819, 2003. 32579

Nyeki, S., Baltensperger, U., Colbeck, I., Jost, D., Weingartner, E., and Gäggeler, H.: The Jungfraujoch high-alpine research station (3454 $\mathrm{m}$ ) as a background clean continental site for the measurement of aerosol parameters, J. Geophys. Res., 103, 6097-6107, 1998. 32579

Padró, L. T., Moore, R. H., Zhang, X., Rastogi, N., Weber, R. J., and Nenes, A.: Mixing state and compositional effects on CCN activity and droplet growth kinetics of size-resolved CCN in an urban environment, Atmos. Chem. Phys., 12, 10239-10255, doi:10.5194/acp-12-102392012, 2012. 32578

Paramonov, M., Aalto, P. P., Asmi, A., Prisle, N., Kerminen, V.-M., Kulmala, M., and Petäjä, T.: The analysis of size-segregated cloud condensation nuclei counter (CCNC) data and its implications for cloud droplet activation, Atmos. Chem. Phys., 13, 10285-10301, doi:10.5194/acp-13-10285-2013, 2013. 32590

30 Petters, M. D. and Kreidenweis, S. M.: A single parameter representation of hygroscopic growth and cloud condensation nucleus activity, Atmos. Chem. Phys., 7, 1961-1971, doi:10.5194/acp-7-1961-2007, 2007. 32584, 32594

\section{ACPD}

13, 32575-32624, 2013

CCN at the
Jungfraujoch

D. Rose et al.

Title Page

Abstract

Introduction

Conclusions

References

Tables

Figures

14

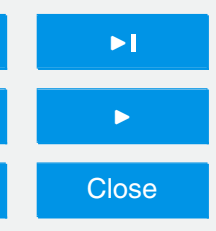

Full Screen / Esc

Printer-friendly Version

Interactive Discussion 
Pöschl, U., Rose, D., and Andreae, M. O.: Climatologies of cloud-related aerosols - Part 2: Particle hygroscopicity and cloud condensation nucleus activity, in: Clouds in the Perturbed Climate System: their Relationship to Energy Balance, Atmospheric Dynamics, and Precipitation, edited by: Heintzenberg, J. and Charlson, R. J., Strüngmann Forum Report, vol. 2, MIT Press, Cambridge, MA, 57-72, 2009. 32584, 32591, 32597

Pringle, K. J., Tost, H., Pozzer, A., Pöschl, U., and Lelieveld, J.: Global distribution of the effective aerosol hygroscopicity parameter for CCN activation, Atmos. Chem. Phys., 10, 5241-5255, doi:10.5194/acp-10-5241-2010, 2010. 32591, 32597

Roberts, G. C. and Nenes, A.: A continuous-flow streamwise thermal-gradient CCN chamber for atmospheric measurements, Aerosol Sci. Tech., 39, 206-221, 2005. 32581

Roberts, G. C., Andreae, M. O., Zhou, J., and Artaxo, P.: Cloud condensation nuclei in the Amazon Basin: "marine" conditions over a continent?, Geophys. Res. Lett., 28, 2807-2810, 2001. 32590

Roberts, G. C., Day, D. A., Russell, L. M., Dunlea, E. J., Jimenez, J. L., Tomlinson, J. M., Collins, D. R., Shinozuka, Y., and Clarke, A. D.: Characterization of particle cloud droplet activity and composition in the free troposphere and the boundary layer during INTEX-B, Atmos. Chem. Phys., 10, 6627-6644, doi:10.5194/acp-10-6627-2010, 2010. 32594

Rose, D., Gunthe, S. S., Mikhailov, E., Frank, G. P., Dusek, U., Andreae, M. O., and Pöschl, U.: Calibration and measurement uncertainties of a continuous-flow cloud condensation nuclei counter (DMT-CCNC): CCN activation of ammonium sulfate and sodium chloride aerosol particles in theory and experiment, Atmos. Chem. Phys., 8, 1153-1179, doi:10.5194/acp-81153-2008, 2008. 32582, 32583, 32587

Rose, D., Nowak, A., Achtert, P., Wiedensohler, A., Hu, M., Shao, M., Zhang, Y., Andreae, M. O., and Pöschl, U.: Cloud condensation nuclei in polluted air and biomass burning smoke near the mega-city Guangzhou, China - Part 1: Size-resolved measurements and implications for the modeling of aerosol particle hygroscopicity and CCN activity, Atmos. Chem. Phys., 10, 3365-3383, doi:10.5194/acp-10-3365-2010, 2010. 32578, 32583, 32584, 32585, 32590, 32591,32597

Rose, D., Gunthe, S. S., Su, H., Garland, R. M., Yang, H., Berghof, M., Cheng, Y. F., Wehner, B., Achtert, P., Nowak, A., Wiedensohler, A., Takegawa, N., Kondo, Y., Hu, M., Zhang, Y., Andreae, M. O., and Pöschl, U.: Cloud condensation nuclei in polluted air and biomass burning smoke near the mega-city Guangzhou, China - Part 2: Size-resolved aerosol chemical composition, diurnal cycles, and externally mixed weakly CCN-active soot particles, Atmos.

\section{ACPD}

13, 32575-32624, 2013

CCN at the

Jungfraujoch

D. Rose et al.

Title Page

Abstract

Introduction

Conclusions

References

Tables

Figures

14

$>1$

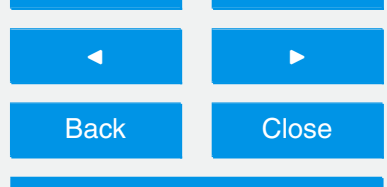

Full Screen / Esc

Printer-friendly Version

Interactive Discussion 
Chem. Phys., 11, 2817-2836, doi:10.5194/acp-11-2817-2011, 2011. 32578, 32584, 32590, 32591, 32593, 32594, 32595, 32597, 32598

Schüpp, M.: Klimatologie der Schweiz, Band III, Witterungsklimatologie, Schweizerische Meteorologische Anstalt, Zürich, Switzerland, 1979. 32580

5 Shinozuka, Y., Clarke, A. D., DeCarlo, P. F., Jimenez, J. L., Dunlea, E. J., Roberts, G. C., Tomlinson, J. M., Collins, D. R., Howell, S. G., Kapustin, V. N., McNaughton, C. S., and Zhou, J.: Aerosol optical properties relevant to regional remote sensing of $\mathrm{CCN}$ activity and links to their organic mass fraction: airborne observations over Central Mexico and the US West Coast during MILAGRO/INTEX-B, Atmos. Chem. Phys., 9, 6727-6742, doi:10.5194/acp-96727-2009, 2009. 32591, 32594, 32597

Sjogren, S., Gysel, M., Weingartner, E., Alfarra, M. R., Duplissy, J., Cozic, J., Crosier, J., Coe, H., and Baltensperger, U.: Hygroscopicity of the submicrometer aerosol at the highalpine site Jungfraujoch, 3580 ma.s.l., Switzerland, Atmos. Chem. Phys., 8, 5715-5729, doi:10.5194/acp-8-5715-2008, 2008. 32579, 32594

15 Su, H., Rose, D., Cheng, Y. F., Gunthe, S. S., Massling, A., Stock, M., Wiedensohler, A., Andreae, M. O., and Pöschl, U.: Hygroscopicity distribution concept for measurement data analysis and modeling of aerosol particle mixing state with regard to hygroscopic growth and CCN activation, Atmos. Chem. Phys., 10, 7489-7503, doi:10.5194/acp-10-7489-2010, 2010. 32585

Weingartner, E., Nyeki, S., and Baltensperger, U.: Seasonal and diurnal variation of aerosol size distributions $(10<D<750 \mathrm{~nm}$ ) at a high-alpine site (Jungfraujoch $3580 \mathrm{~m}$ a.s.l.), J. Geophys. Res., 104, 26809-26820, 1999. 32581

Wiedensohler, A., Birmili, W., Nowak, A., Sonntag, A., Weinhold, K., Merkel, M., Wehner, B., Tuch, T., Pfeifer, S., Fiebig, M., Fjäraa, A. M., Asmi, E., Sellegri, K., Depuy, R., Venzac, H., Villani, P., Laj, P., Aalto, P., Ogren, J. A., Swietlicki, E., Williams, P., Roldin, P., Quincey, P., Hüglin, C., Fierz-Schmidhauser, R., Gysel, M., Weingartner, E., Riccobono, F., Santos, S., Grüning, C., Faloon, K., Beddows, D., Harrison, R., Monahan, C., Jennings, S. G., O'Dowd, C. D., Marinoni, A., Horn, H.-G., Keck, L., Jiang, J., Scheckman, J., McMurry, P. H., Deng, Z., Zhao, C. S., Moerman, M., Henzing, B., de Leeuw, G., Löschau, G., and Bastian, S.: Mobility particle size spectrometers: harmonization of technical standards and data structure to facilitate high quality long-term observations of atmospheric particle number size distributions, Atmos. Meas. Tech., 5, 657-685, doi:10.5194/amt-5-657-2012, 2012. 32583, 32588

$\mathrm{CCN}$ at the Jungfraujoch

D. Rose et al.

Title Page

Abstract Introduction

Conclusions

References

Tables

Figures

14

$\rightarrow 1$

4

Back

$\triangleright$

Close

Full Screen / Esc

Printer-friendly Version

Interactive Discussion 
Wu, Z. J., Poulain, L., Henning, S., Dieckmann, K., Birmili, W., Merkel, M., van Pinxteren, D., Spindler, G., Müller, K., Stratmann, F., Herrmann, H., and Wiedensohler, A.: Relating particle hygroscopicity and CCN activity to chemical composition during the HCCT-2010 field campaign, Atmos. Chem. Phys., 13, 7983-7996, doi:10.5194/acp-13-7983-2013, 2013. 32578,

\section{1}

Zhang, Q., Meng, J., Quan, J., Gao, Y., Zhao, D., Chen, P., and He, H.: Impact of aerosol composition on cloud condensation nuclei activity, Atmos. Chem. Phys., 12, 3783-3790, doi:10.5194/acp-12-3783-2012, 2012. 32578, 32589

\section{ACPD}

13, 32575-32624, 2013

$\mathrm{CCN}$ at the Jungfraujoch

D. Rose et al.

Title Page

Abstract

Conclusions

\section{Tables}

14

4

Back

Full Screen / Esc

Printer-friendly Version

Interactive Discussion 
Table 1. Comparison between the total CCN concentration measured with the MPI CCNC and the PSI CCNC for different operation modes (Fig. 2). The abbreviation "poly" means the operation mode when the total CCN concentration was recorded directly by the CCNC (polydisperse mode) and "mono" means the operation mode when the total CCN concentration was calculated from the size-resolved CCN efficiency spectrum (monodisperse mode). The table lists the average total CCN concentrations measured by the two CCNCs for each comparison, the average relative deviation between the concentrations of the MPI and the PSI CCNC, and the number of data points, $n$. The first two lines display the supersaturation levels of the PSI and the MPI CCNC and the third line is the relative deviation of the supersaturation of the MPI CCNC from the one of the PSI CCNC.

\begin{tabular}{|c|c|c|c|c|c|}
\hline \multicolumn{6}{|l|}{ supersaturation } \\
\hline$S(\mathrm{PSI})[\%]$ & 0.099 & 0.20 & 0.29 & 0.48 & 0.67 \\
\hline$S(\mathrm{MPI})[\%]$ & 0.079 & 0.17 & 0.27 & 0.46 & 0.66 \\
\hline rel. dev. from $S(\mathrm{PSI})[\%]$ & -20.2 & -15.0 & -6.9 & -4.2 & -1.5 \\
\hline \multicolumn{6}{|l|}{ poly-poly comparison } \\
\hline$N_{\text {CCN, tot,p }}(\mathrm{PSI})\left[\mathrm{cm}^{-3}\right]$ & 13 & 20 & 31 & 40 & 48 \\
\hline$N_{\mathrm{CCN}, \text { tot, } \mathrm{p}}(\mathrm{MPI})\left[\mathrm{cm}^{-3}\right]$ & 6 & 17 & 29 & 38 & 45 \\
\hline rel. dev. from $N_{\mathrm{CCN}, \text { tot, } \mathrm{p}}(\mathrm{PSI})[\%]$ & -52.3 & -12.1 & -6.0 & -5.7 & -5.3 \\
\hline$n$ & 16 & 15 & 15 & 15 & 15 \\
\hline \multicolumn{6}{|l|}{ poly-mono comparison } \\
\hline$N_{\mathrm{CCN}, \text { tot,p }}(\mathrm{PSI})\left[\mathrm{cm}^{-3}\right]$ & 57 & 101 & 100 & 131 & 166 \\
\hline$N_{\mathrm{CCN}, \mathrm{tot}, \mathrm{m}}(\mathrm{MPI})\left[\mathrm{cm}^{-3}\right]$ & 41 & 111 & 120 & 162 & 194 \\
\hline $\begin{array}{l}\text { rel. dev. from } N_{C C N, \text { tot,p }}(\mathrm{PSI})[\%] \\
\text { rel. dev. from } N_{\mathrm{CCN}, \text { tot,p }}(\mathrm{PSI}) \text { accounting }\end{array}$ & -27.1 & +9.9 & +19.8 & +23.8 & +16.9 \\
\hline for deviation in poly-poly comparsion [\%] & +25.2 & +22.0 & +25.8 & +29.5 & +22.2 \\
\hline$n$ & 27 & 46 & 32 & 29 & 27 \\
\hline
\end{tabular}

13, 32575-32624, 2013

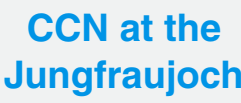

D. Rose et al.

Title Page

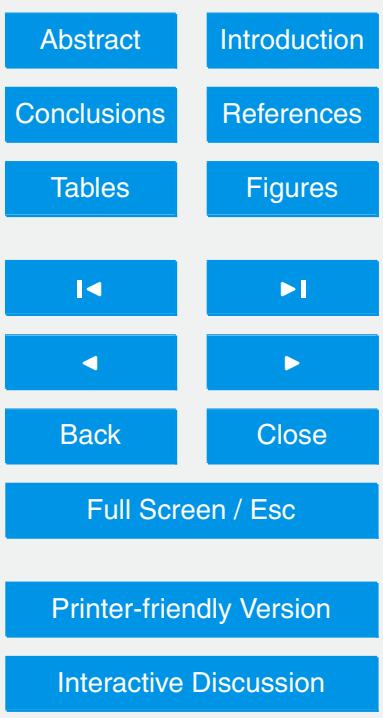


Table 2. Characteristic CCN parameters (arithmetic mean value \pm one standard deviation) averaged over the entire CCN measurement period of the CLACE- 6 campaign (3-13 March 2007), and over other indicated periods: midpoint activation diameter $\left(D_{\mathrm{a}}\right)$, maximum activated fraction (MAF), CDF standard deviation $\left(\sigma_{\mathrm{a}}\right)$, heterogeneity parameter $\left(\sigma_{\mathrm{a}} / D_{\mathrm{a}}\right)$, hygroscopicity parameter $\left(\kappa_{\mathrm{a}}\right)$, total $\mathrm{CN}$ concentration $\left(N_{\mathrm{CN}, \text { tot }}\right)$, total $\mathrm{CCN}$ concentration $\left(N_{\mathrm{CCN}, \text { tot, } \mathrm{m}}\right)$, total CCN efficiency $\left(N_{\mathrm{CCN}, \text { tot, } \mathrm{m}} / N_{\mathrm{CN}, \text { tot }}\right)$, and available number of data points of CCN efficiency spectra $\left(n_{\text {es }}\right)$ and of size distributions $\left(n_{\text {sd }}\right)$.

\begin{tabular}{|c|c|c|c|c|c|c|c|c|c|c|}
\hline $\begin{array}{l}S \\
{[\%]}\end{array}$ & $\begin{array}{c}D_{\mathrm{a}} \\
{[\mathrm{nm}]}\end{array}$ & $\begin{array}{l}\text { MAF } \\
{[\mathrm{nm}]}\end{array}$ & $\sigma_{\mathrm{a}}$ & $\sigma_{\mathrm{a}} / D_{\mathrm{a}}$ & $\kappa_{\mathrm{a}}$ & $\begin{array}{l}N_{\mathrm{CN}, \text { tot }} \\
{\left[\mathrm{cm}^{-3}\right]}\end{array}$ & $\begin{array}{c}N_{\mathrm{CCN}, \text { tot, } \mathrm{m}} \\
{\left[\mathrm{cm}^{-3}\right]}\end{array}$ & $N_{\mathrm{CCN}, \mathrm{tot}, \mathrm{m}} / N_{\mathrm{CN}, \text { tot }}$ & $n_{\mathrm{es}}$ & $n_{\mathrm{sd}}$ \\
\hline \multicolumn{11}{|c|}{ entire measurement period } \\
\hline 0.079 & $171.7 \pm 14.8$ & $0.97 \pm 0.11$ & $16.4 \pm 10.5$ & $0.09 \pm 0.06$ & $0.43 \pm 0.09$ & & $51 \pm 55$ & $0.13 \pm 0.05$ & 75 & 48 \\
\hline 0.17 & $114.5 \pm 12.8$ & $1.01 \pm 0.14$ & $15.4 \pm 10.0$ & $0.13 \pm 0.08$ & $0.32 \pm 0.11$ & & $116 \pm 94$ & $0.29 \pm 0.10$ & 79 & 49 \\
\hline 0.27 & $88.4 \pm 14.7$ & $1.02 \pm 0.12$ & $14.7 \pm 9.4$ & $0.17 \pm 0.10$ & $0.30 \pm 0.14$ & & $149 \pm 115$ & $0.39 \pm 0.14$ & 85 & 54 \\
\hline 0.46 & $65.1 \pm 9.8$ & $1.01 \pm 0.11$ & $11.6 \pm 6.0$ & $0.17 \pm 0.08$ & $0.25 \pm 0.10$ & & $197 \pm 138$ & $0.51 \pm 0.14$ & 81 & 50 \\
\hline 0.66 & $52.8 \pm 7.8$ & $0.98 \pm 0.13$ & $10.5 \pm 4.8$ & $0.20 \pm 0.08$ & $0.23 \pm 0.12$ & & $236 \pm 149$ & $0.60 \pm 0.15$ & 78 & 48 \\
\hline all & & & & & $0.31 \pm 0.13$ & $383 \pm 236$ & & & 398 & 249 \\
\hline \multicolumn{11}{|c|}{ air masses from easterly directions (11-13 Mar 2007) } \\
\hline 0.079 & $159.2 \pm 5.2$ & $0.91 \pm 0.08$ & $9.6 \pm 6.0$ & $0.06 \pm 0.03$ & $0.52 \pm 0.05$ & & n.a. & n.a. & 17 & 0 \\
\hline 0.17 & $102.7 \pm 11.0$ & $0.98 \pm 0.08$ & $10.7 \pm 8.4$ & $0.10 \pm 0.08$ & $0.44 \pm 0.12$ & & n.a. & n.a. & 19 & 0 \\
\hline 0.27 & $75.5 \pm 10.2$ & $0.97 \pm 0.07$ & $13.7 \pm 6.9$ & $0.18 \pm 0.08$ & $0.45 \pm 0.14$ & & n.a. & n.a. & 20 & 0 \\
\hline 0.46 & $57.6 \pm 7.1$ & $1.00 \pm 0.06$ & $9.4 \pm 5.0$ & $0.16 \pm 0.09$ & $0.35 \pm 0.12$ & & n.a. & n.a. & 20 & 0 \\
\hline 0.66 & $46.2 \pm 6.1$ & $0.98 \pm 0.05$ & $8.2 \pm 3.5$ & $0.18 \pm 0.09$ & $0.34 \pm 0.17$ & & n.a. & n.a. & 19 & 0 \\
\hline all & & & & & $0.42 \pm 0.14$ & n.a. & & & 95 & 0 \\
\hline \multicolumn{11}{|c|}{ rest of campaign (excluding easterly air masses and precipitation event (9/10 Mar 2007, Sect. 3.5)) } \\
\hline 0.079 & $175.6 \pm 14.8$ & $1.00 \pm 0.12$ & $18.5 \pm 10.8$ & $0.10 \pm 0.06$ & $0.40 \pm 0.09$ & & $47 \pm 51$ & $0.12 \pm 0.05$ & 56 & 46 \\
\hline 0.17 & $118.1 \pm 11.1$ & $1.03 \pm 0.12$ & $16.5 \pm 10.2$ & $0.14 \pm 0.08$ & $0.29 \pm 0.07$ & & $114 \pm 88$ & $0.30 \pm 0.09$ & 56 & 45 \\
\hline 0.27 & $91.2 \pm 12.7$ & $1.04 \pm 0.10$ & $15.4 \pm 10.0$ & $0.17 \pm 0.10$ & $0.26 \pm 0.10$ & & $151 \pm 115$ & $0.41 \pm 0.13$ & 60 & 49 \\
\hline 0.46 & $67.3 \pm 9.2$ & $1.03 \pm 0.10$ & $11.9 \pm 6.1$ & $0.17 \pm 0.08$ & $0.22 \pm 0.07$ & & $200 \pm 139$ & $0.53 \pm 0.12$ & 56 & 45 \\
\hline 0.66 & $54.7 \pm 7.0$ & $1.01 \pm 0.11$ & $11.1 \pm 4.9$ & $0.20 \pm 0.08$ & $0.20 \pm 0.08$ & & $239 \pm 141$ & $0.63 \pm 0.12$ & 54 & 43 \\
\hline all & & & & & $0.27 \pm 0.11$ & $369 \pm 223$ & & & 282 & 228 \\
\hline
\end{tabular}

\section{$\mathrm{CCN}$ at the Jungfraujoch}

D. Rose et al.

\section{Title Page}

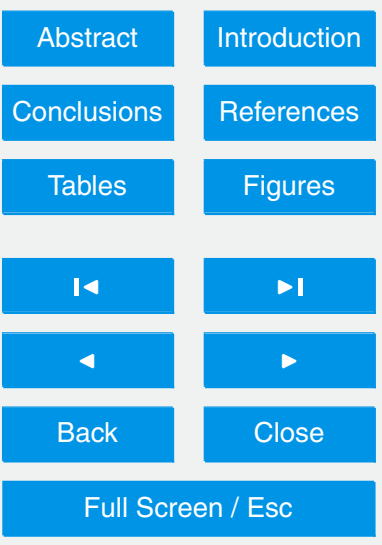

Printer-friendly Version

Interactive Discussion 
Table A1. Notation (frequently used symbols).

\begin{tabular}{|c|c|}
\hline Symbol & Quantity, Unit \\
\hline$D$ & dry particle diameter, $\mathrm{nm}$ \\
\hline$D_{\mathrm{a}}$ & midpoint activation diameter of $\mathrm{CCN}$ efficiency spectra, $\mathrm{nm}$ \\
\hline $\mathrm{d} N_{\mathrm{CCN}} / \mathrm{d} \log D$ & $\mathrm{CCN}$ number size distribution at a certain $S, \mathrm{~cm}^{-3}$ \\
\hline $\mathrm{d} N_{\mathrm{CN}} / \mathrm{d} \log D$ & $\mathrm{CN}$ number size distribution, $\mathrm{cm}^{-3}$ \\
\hline $\begin{array}{l}f_{\text {inorg }} \\
f_{\text {org }} \\
\text { MAF }\end{array}$ & $\begin{array}{l}\text { inorganic mass fraction determined by aerosol mass spectrometer measurements } \\
\text { organic mass fraction determined by aerosol mass spectrometer measurements } \\
\text { maximum activated fraction obtained by fitting a cumulative Gaussian distribution } \\
\text { function (CDF) to the CCN efficiency spectrum }\end{array}$ \\
\hline$N_{\mathrm{CCN}}$ & $\begin{array}{l}\text { bin-resolved number concentration of } \mathrm{CCN} \text { at certain } S \text { from monodisperse mea- } \\
\text { surements, } \mathrm{cm}^{-3}\end{array}$ \\
\hline$N_{\mathrm{CCN}, \text { tot }, \mathrm{m}}$ & $\begin{array}{l}\text { total number concentration of } \mathrm{CCN} \text { at certain } S \text { calculated from monodisperse mea- } \\
\text { surements (by integrating the } \mathrm{CCN} \text { size distribution) } \mathrm{cm}^{-3}\end{array}$ \\
\hline$N_{\mathrm{CCN}, \text { tot,p }}$ & $\begin{array}{l}\text { total number concentration of } \mathrm{CCN} \text { at certain } S \text { directly determined by polydisperse } \\
\text { measurements, } \mathrm{cm}^{-3}\end{array}$ \\
\hline$N_{\mathrm{CN}}$ & bin-resolved number concentration of $\mathrm{CN}$ from monodisperse measurements, $\mathrm{cm}^{-3}$ \\
\hline$N_{\mathrm{CN}, \text { tot }}$ & $\begin{array}{l}\text { total number concentration of } \mathrm{CN} \text { calculated by integrating the } \mathrm{CN} \text { size distribution, } \\
\mathrm{cm}^{-3}\end{array}$ \\
\hline$S$ & supersaturation of the $\mathrm{CCN}$ counter, \% \\
\hline$\kappa$ & effective hygroscopicity parameter \\
\hline$\kappa_{\mathrm{a}}$ & hygroscopicity parameter derived from $D_{\mathrm{a}}$ via Köhler theory \\
\hline$\kappa_{\text {inorg }}$ & hygroscopicity of inorganic particulate matter \\
\hline$\kappa_{\text {org }}$ & hygroscopicity of organic particulate matter \\
\hline & standard deviation of a CDF fit to the CCN efficiency spectrum, $\mathrm{nm}$ \\
\hline$\sigma_{\mathrm{a}} / D_{\mathrm{a}}$ & normalized CDF standard deviation or heterogeneity parameter \\
\hline
\end{tabular}

$\mathrm{CCN}$ at the Jungfraujoch

D. Rose et al.

\section{Title Page}

Abstract Introduction

Conclusions

References

Tables

Figures

14

$\rightarrow$

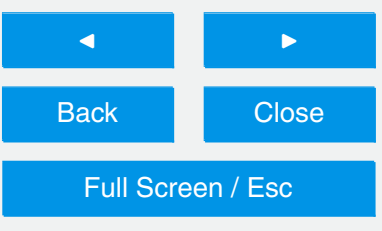

Printer-friendly Version

Interactive Discussion 


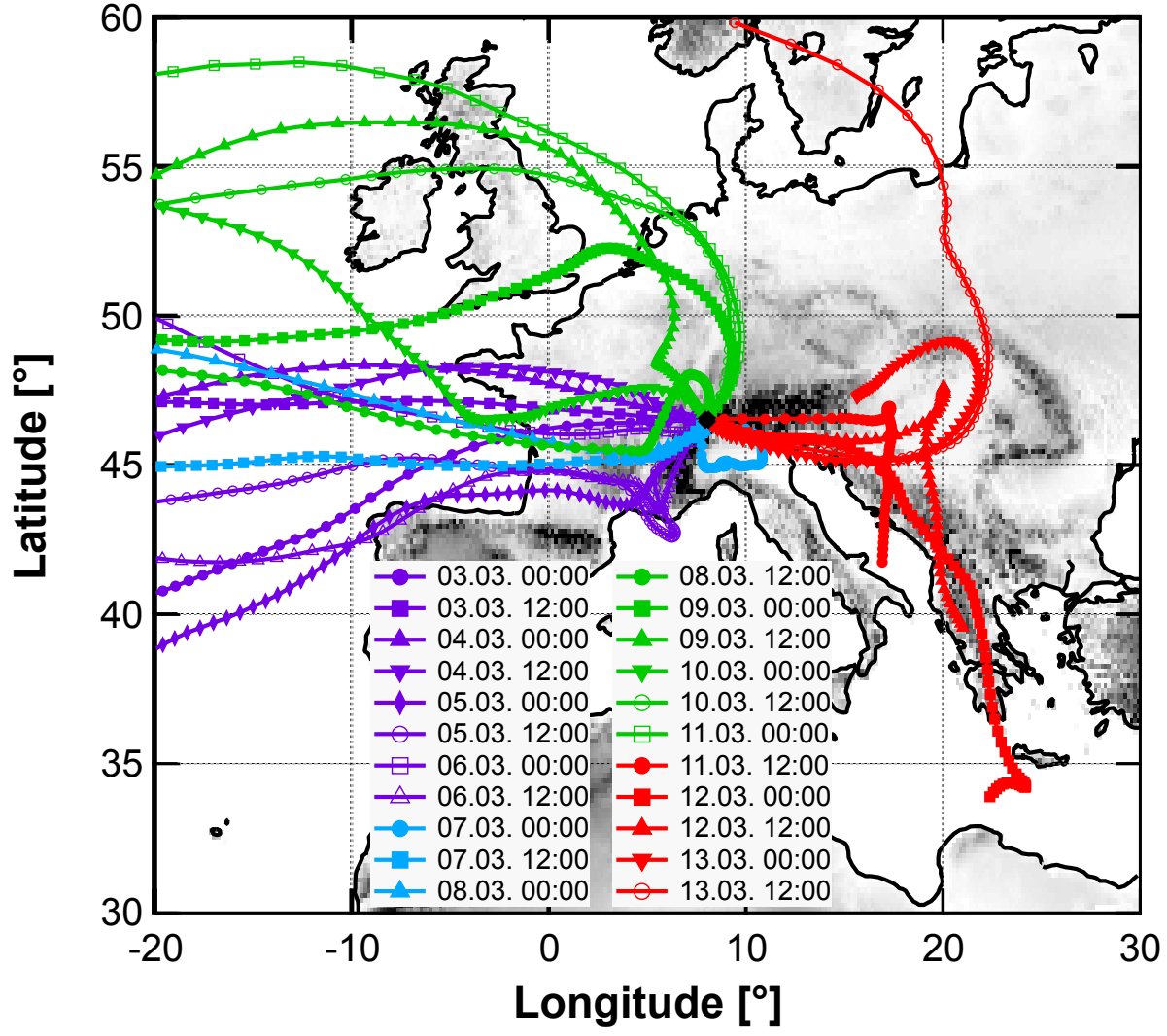

Fig. 1. Location of the high-alpine research station Jungfraujoch ( 3580 m a.s.l., black dot) with 3 day backward trajectories. Starting times are indicated in the legend and given in UTC. Colors represent different time periods in which the air masses originated from different main directions: easterly (red) and others (purple, blue, green).

\section{ACPD}

13, 32575-32624, 2013

\section{CCN at the Jungfraujoch}

D. Rose et al.

Title Page

Abstract

Conclusions

Tables

14

4

Back

Full Screen / Esc

Printer-friendly Version

Interactive Discussion 


\section{ACPD}
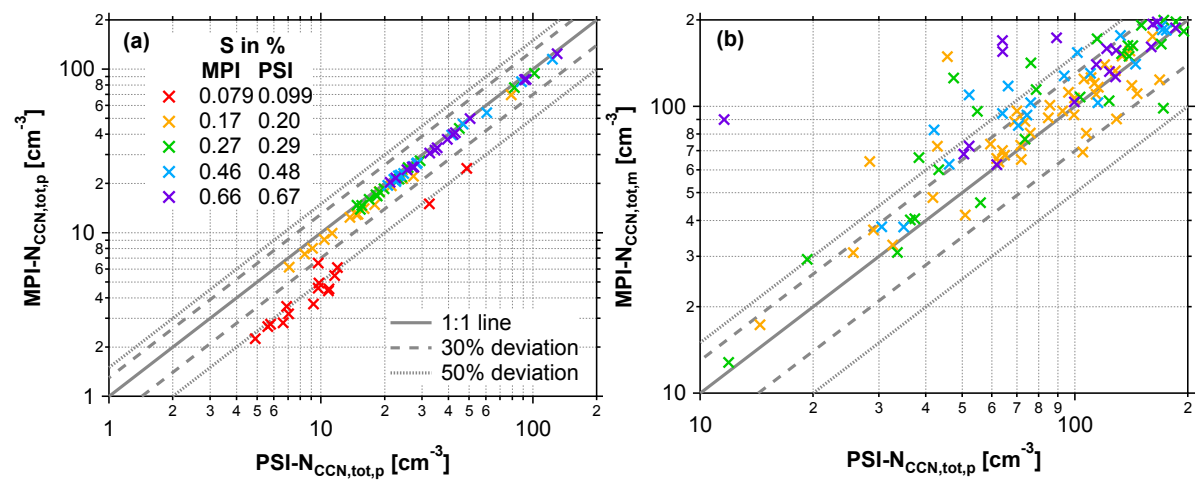

Fig. 2. Scatter plot of $C C N$ number concentrations at different supersaturation levels measured by two different DMT CCN counters operated in parallel by MPI and PSI. Comparisons were made for (a) the period when both the CCNCs were operated in polydisperse mode (13 March 18:00 LT to 14 March 09:30 LT; number of data points, $n=76$ ), and (b) for the time when the PSI and MPI CCNCs were operated in polydisperse and monodisperse mode, respectively (3-13 March; $n=161$ ). Note that the supersaturation levels were not equal for the two CCN counters (see legend). Therefore the lowest $S$-level was not displayed in (b). Linear least squares fits through all data points at $S \geq 0.27 \%$ yielded correlation coefficients $\left(R^{2}\right)$ and slopes $(m)$ of $R^{2}=0.99$ and $m=0.94(n=45)$ in (a) and $R^{2}=0.82$ and $m=0.85(n=88)$ in (b). The two methods in (b) correlate with slopes of $0.95,0.95$, and $0.94\left(R^{2}=0.69,0.75,0.90\right)$ for the individual supersaturation levels at $0.27 \%, 0.46 \%$, and $0.66 \%$.

\section{$\mathrm{CCN}$ at the Jungfraujoch}

D. Rose et al.

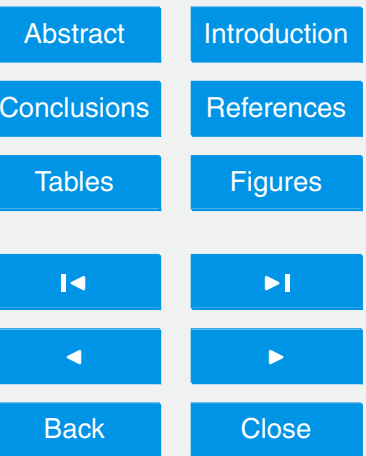

Full Screen / Esc

Interactive Discussion 


\section{ACPD}

13, 32575-32624, 2013
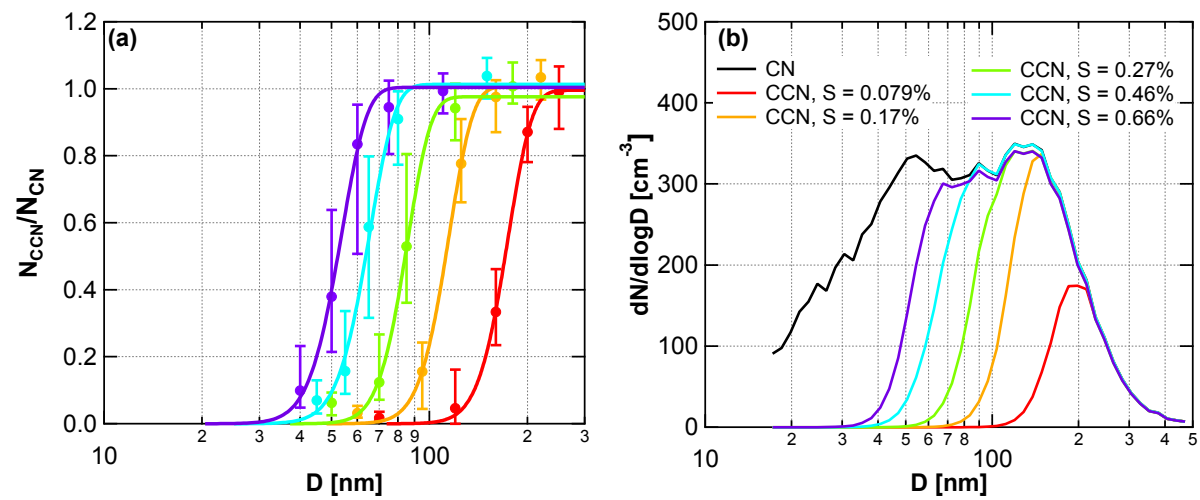

\section{$\mathrm{CCN}$ at the Jungfraujoch}

D. Rose et al.

\section{Title Page}

Abstract Introduction

Conclusions

References

Tables

Figures

14

$\rightarrow$

Fig. 3. (a) Average CCN efficiency spectra for the period of 3-13 March 2007 and (b) average CCN and CN size distributions for the period of 3-11 March 2007. Data points are median values and error bars extend from the 25th to the 75th percentile. Lines in (a) are CDF fits to the median values. $\mathrm{CCN}$ size distributions in (b) are calculated by multiplying the median $\mathrm{CCN}$ efficiency spectra with the median CN size distribution.

$\triangleright$

4

Back

Close

Full Screen / Esc

Printer-friendly Version

Interactive Discussion 


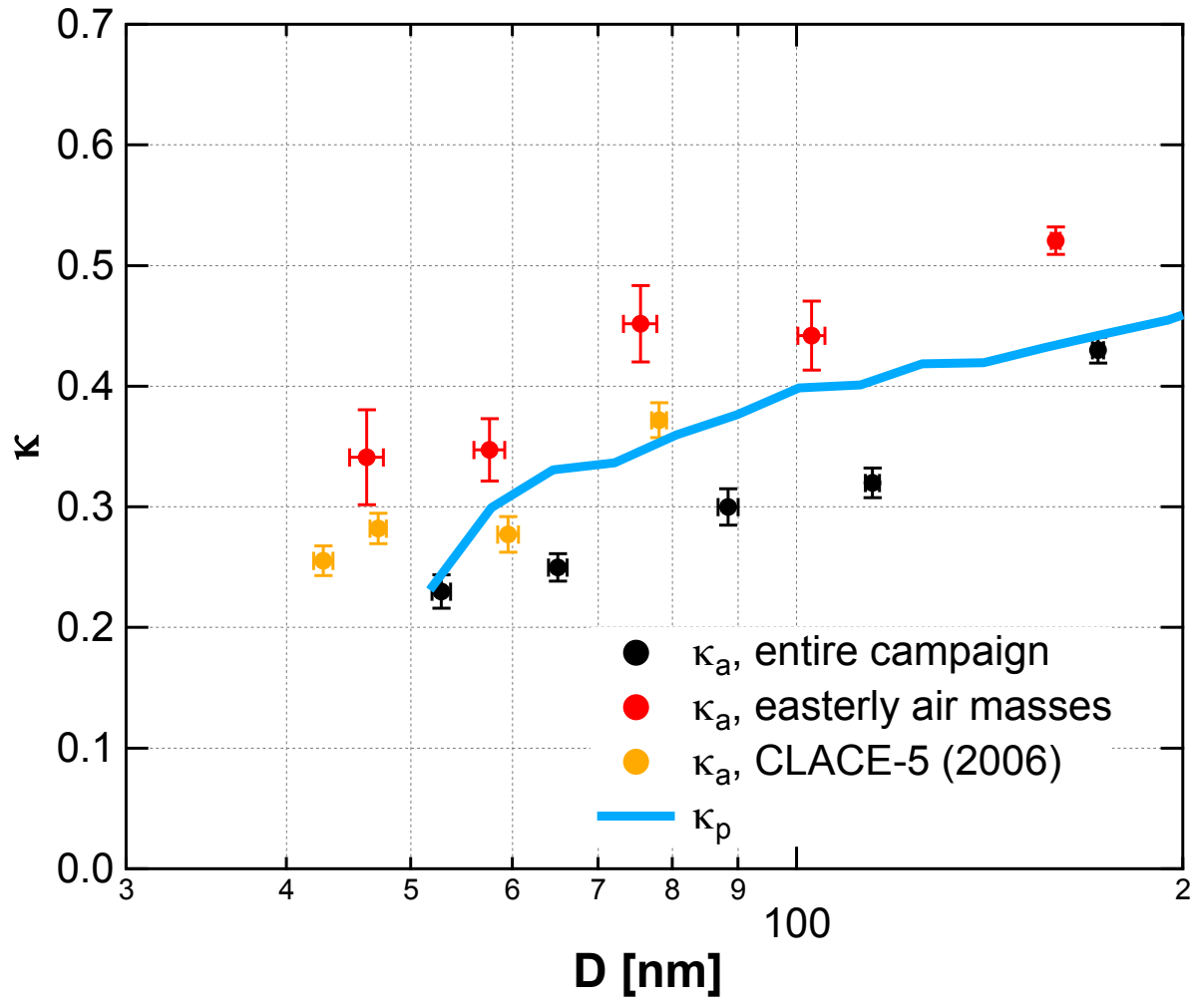

Fig. 4. Hygroscopicity parameter $\kappa_{\mathrm{a}}$ as a function of the particle diameter averaged over the entire measurement period (3-13 March 2007), the period of easterly air masses, and the CLACE-5 campaign (in February/March 2006). Data points are arithmetic mean values and error bars indicate the standard error. The blue line is the predicted hygroscopicity parameter $\kappa_{\mathrm{p}}$ as inferred from the average organic and inorganic particle mass fraction determined by AMS measurements (Sect. 3.4).

\section{ACPD}

13, 32575-32624, 2013

CCN at the Jungfraujoch

D. Rose et al.

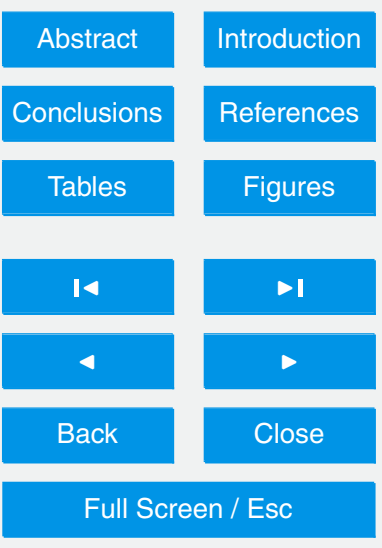

Printer-friendly Version

Interactive Discussion 


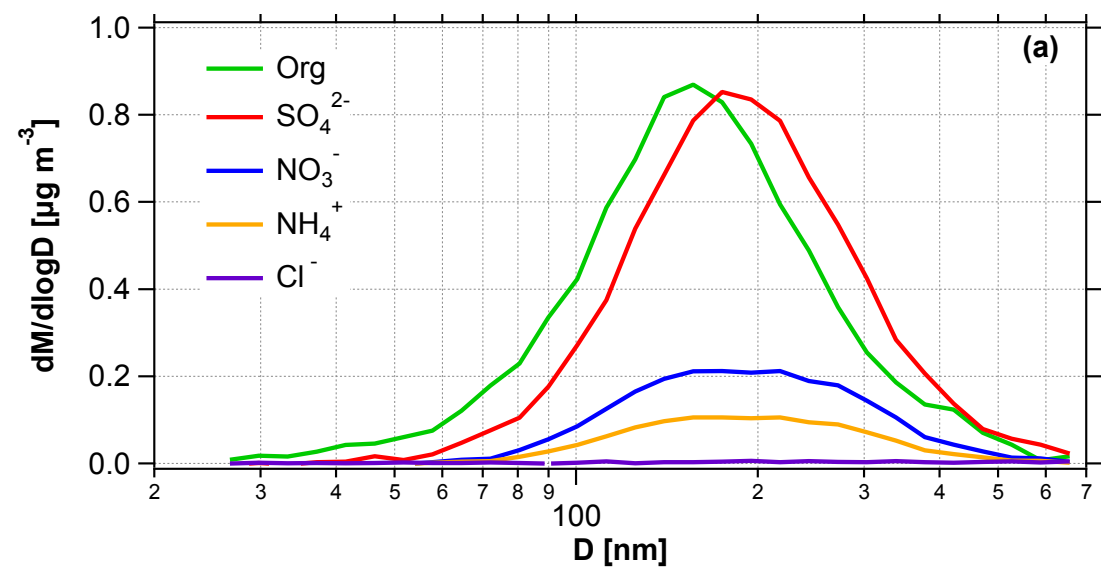

\section{ACPD}

13, 32575-32624, 2013

\section{$\mathrm{CCN}$ at the Jungfraujoch}

D. Rose et al.
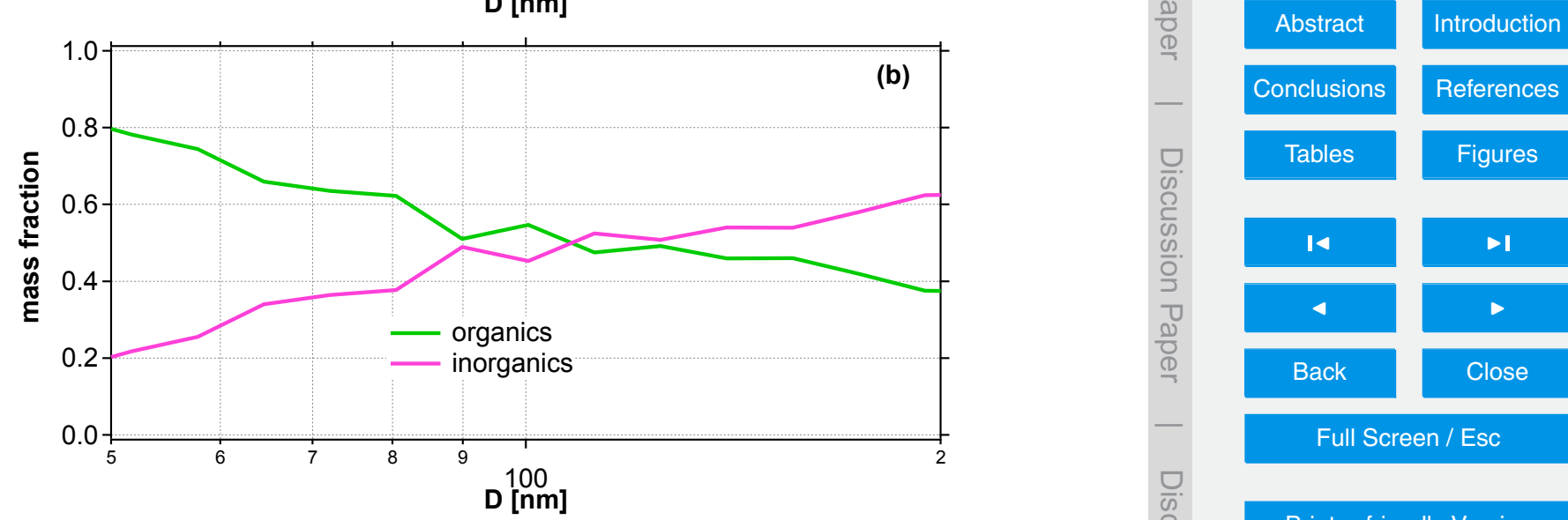

Printer-friendly Version

Fig. 5. Average size distributions of (a) organic, sulfate, nitrate, ammonia, and chloride mass concentrations and (b) organic and inorganic mass fractions. The x-axis specifies the mobility equivalent particle diameter, which was calculated by division of the AMS vacuum aerodynamic diameter through a density-scaling factor of 1.5 .

Interactive Discussion 


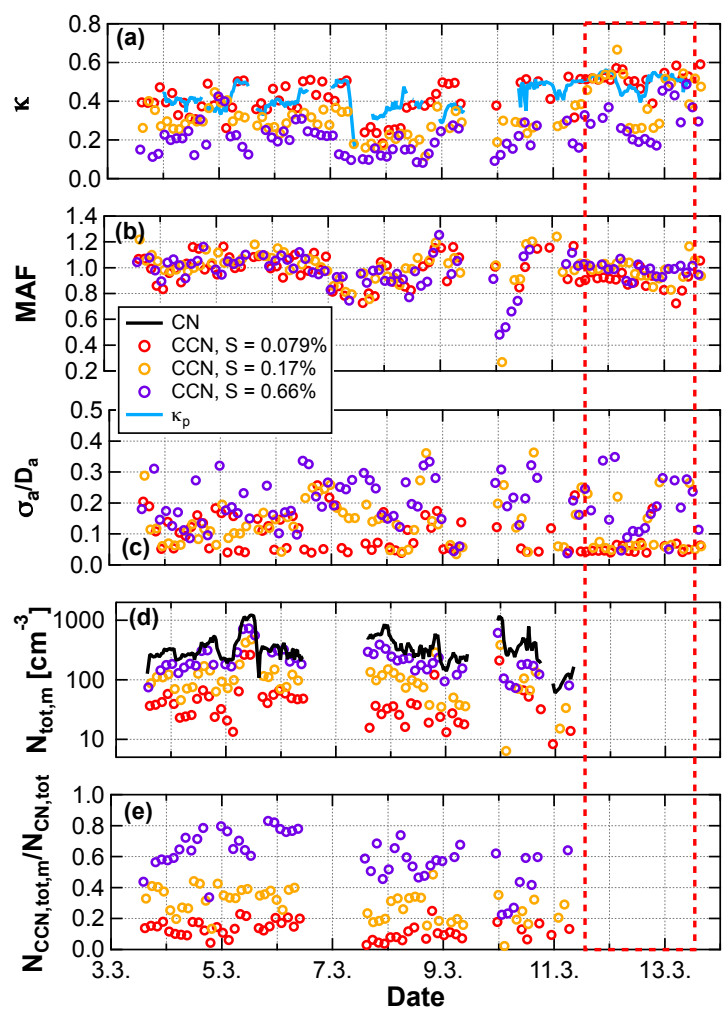

Fig. 6. Time series of characteristic CCN parameters observed at three different levels of supersaturation $(S=0.079 \%, 0.17 \%$, and $0.66 \%)$ : (a) effective hygroscopicity parameter $\left(\kappa_{\mathrm{a}}\right)$, (b) maximum activated fraction (MAF), (c) heterogeneity parameter $\left(\sigma_{a} / D_{a}\right)$, (d) total $C C N$ and $\mathrm{CN}$ number concentration, and (e) total CCN efficiency $\left(N_{\mathrm{CCN}, \text { tot, }} / N_{\mathrm{CN}, \text { tot }}\right)$. Note that the data points of $N_{\mathrm{CN} \text {,tot }}$ are shown only for times when both CCN and SMPS data were available. The blue line in (a) is the predicted hygroscopicity parameter $k_{\mathrm{p}}$ as inferred from the organic and inorganic particle mass fraction determined by AMS measurements (Sect. 3.4). The red dashed box indicates the time period of easterly air mass origin (Fig. 1).
ACPD

13, 32575-32624, 2013

\section{$\mathrm{CCN}$ at the Jungfraujoch}

D. Rose et al.

Title Page
Abstract

Conclusions

Tables

14

4

Back
Introduction

References

Figures

$>1$

$>$

Close

\section{Full Screen / Esc}

Printer-friendly Version

Interactive Discussion 


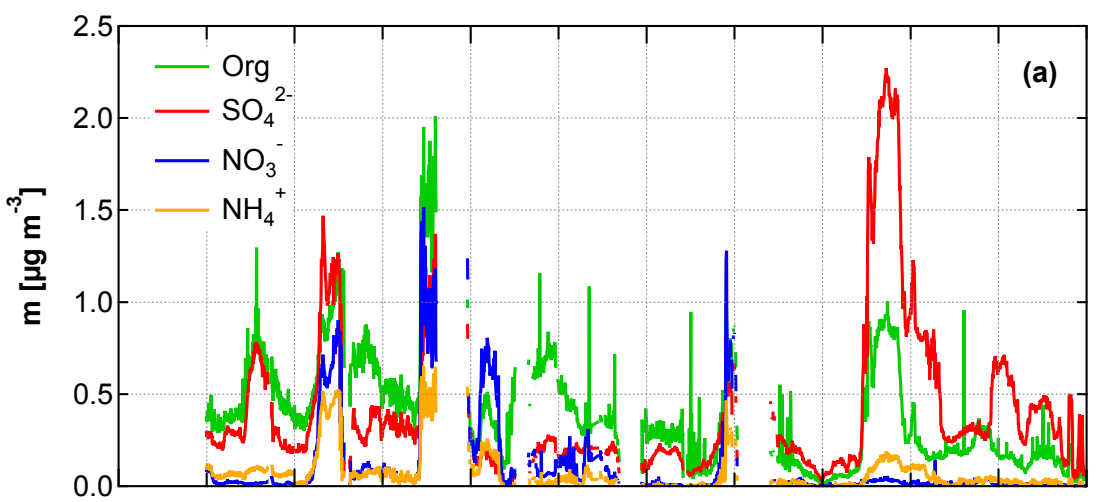

\section{ACPD}

13, 32575-32624, 2013

\section{$\mathrm{CCN}$ at the Jungfraujoch}

D. Rose et al.

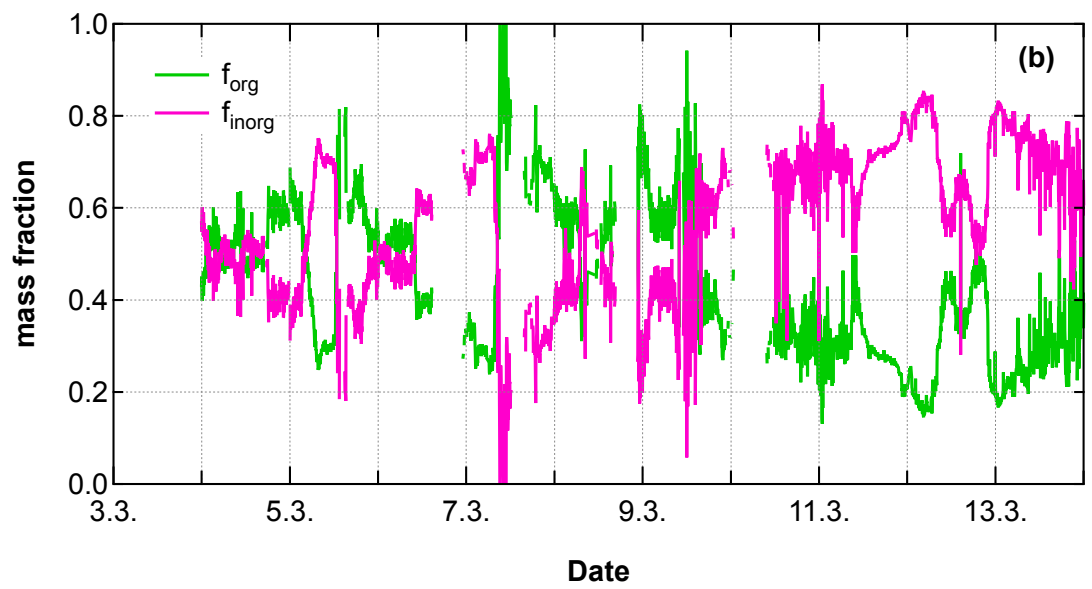

Title Page

Abstract

Conclusions

Tables

14

4

Back
Introduction

References

Figures

$\rightarrow$

$>$

Close

Full Screen / Esc

Printer-friendly Version

Interactive Discussion

Fig. 7. Time series of AMS derived parameters: (a) total mass concentrations of organic species, sulfate, nitrate, and ammonia (integrated over the full AMS size range, $D_{\mathrm{va}}=40$ $1000 \mathrm{~nm}$ ), and (b) organic and inorganic mass fractions calculated from the mass concentrations shown in (a). Due to average chloride concentrations of $\sim 0$ no time series was shown for $\mathrm{Cl}^{-}$in (a). 

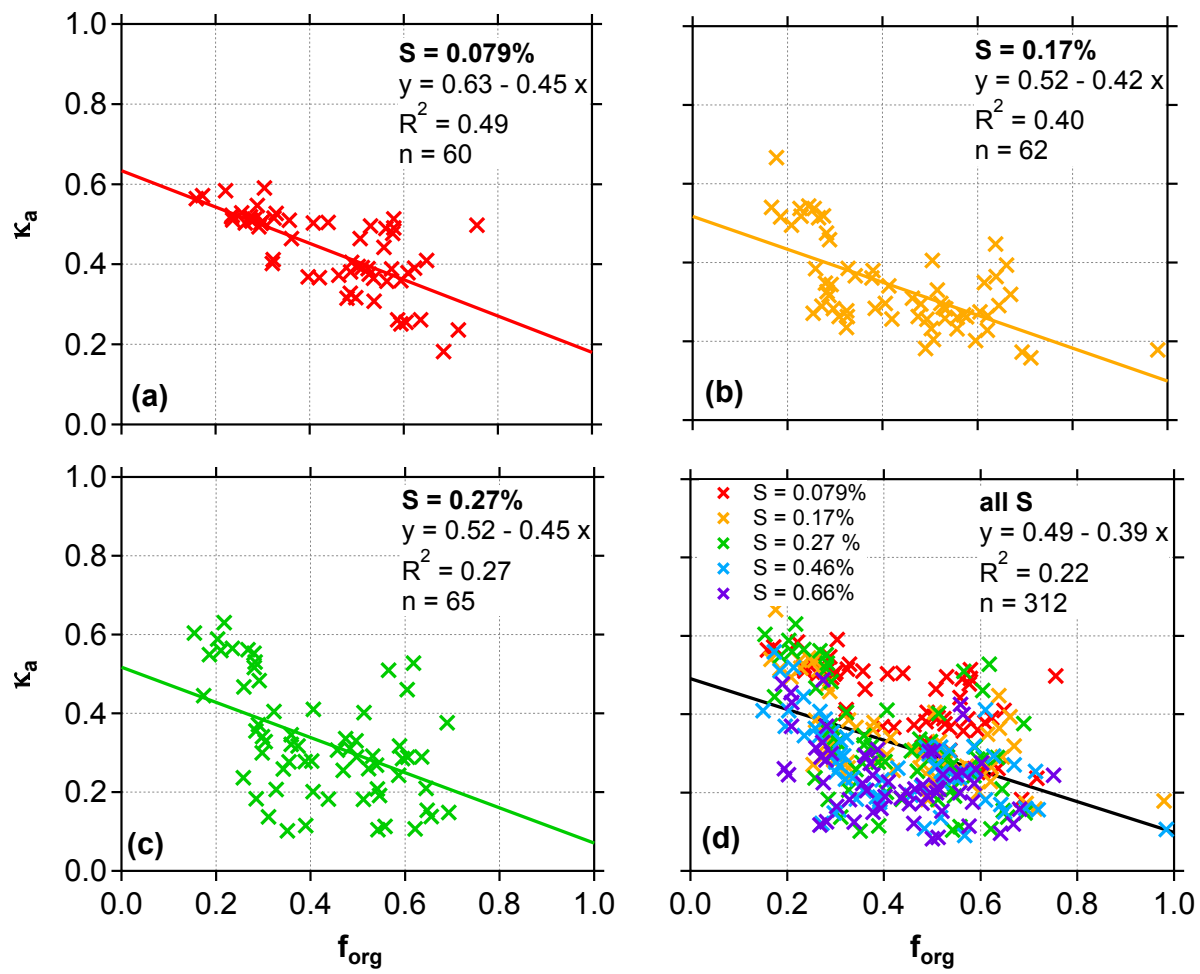

Fig. 8. Correlation between the observed effective hygroscopicity parameter of CCN active particles $\left(\kappa_{\mathrm{a}}\right)$ and the total organic mass fraction $\left(f_{\text {org }}\right)$ determined by AMS measurements (integrated over $D_{\mathrm{va}}=40-1000 \mathrm{~nm}$ ). The $\kappa_{\mathrm{a}}$ values are plotted for (a) $S=0.079 \%$, (b) $S=0.17 \%$, (c) $S=0.27 \%$, and (d) for all supersaturation levels.
ACPD

13, 32575-32624, 2013

CCN at the Jungfraujoch

D. Rose et al.

Title Page
Abstract

Conclusions

Tables

14

4

Back Introduction

\section{References}

Figures

$\Delta$

$\triangleright$

Close

\section{Full Screen / Esc}

Printer-friendly Version

Interactive Discussion 

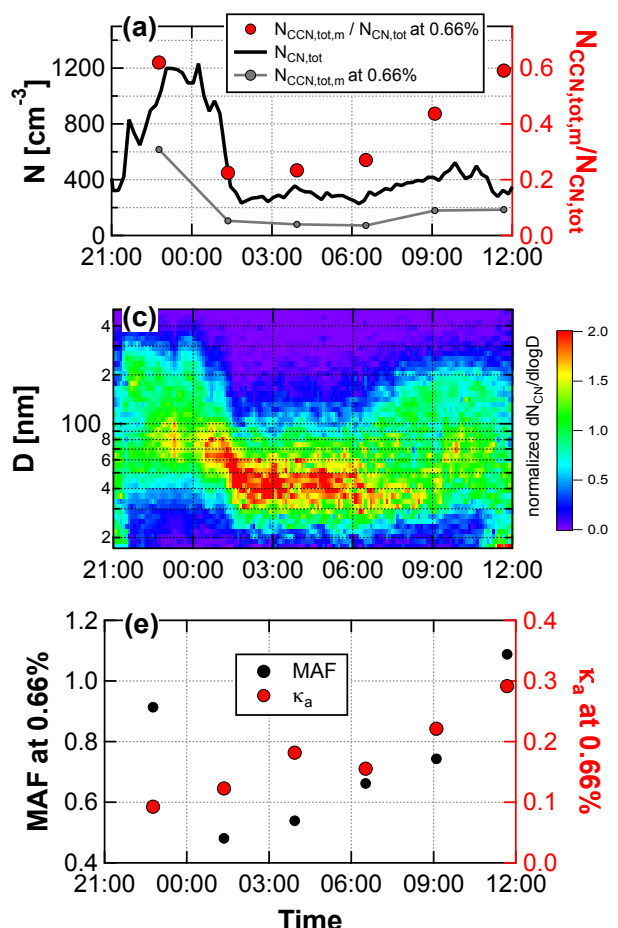
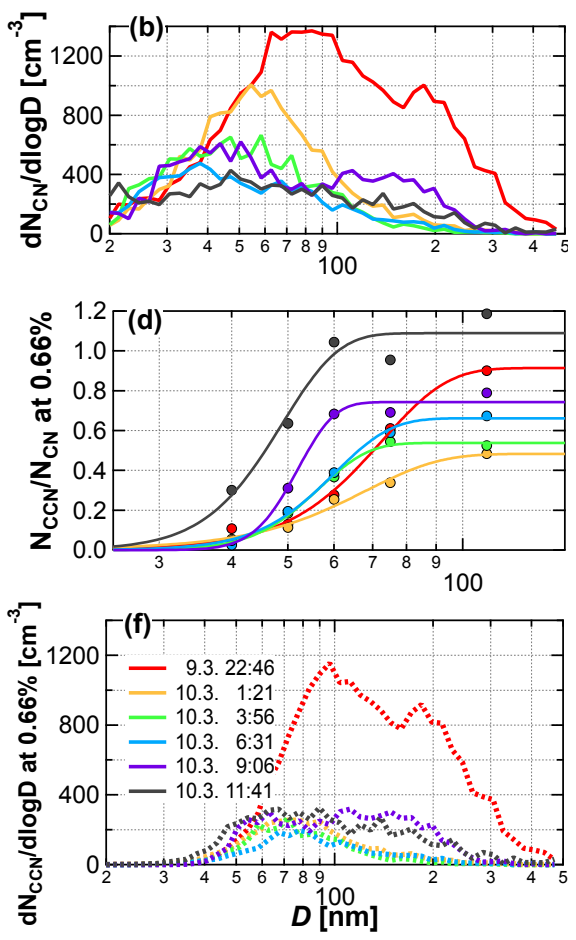

Fig. 9. Temporal evolution of several aerosol and CCN parameters (all at $S=0.66 \%$ ) between 9 March 21:00 LT and 10 March 12:00 LT. In the left column of this figure parameters are plotted against time: (a) total particle number concentration ( $N_{\mathrm{CN} \text {,tot }}$, black) and total $\mathrm{CCN}$ concentration $\left(N_{\mathrm{CCN}, \text { tot, } \mathrm{m}}(S=0.66 \%)\right.$, grey) on the left axis and total CCN efficiency at $S=0.66 \%$ on the right axis (red dots); (c) particle number size distribution normalized to $N_{\mathrm{CN} \text {,tot }}$; (e) maximum activated fraction (MAF, black dots) on the left axis and hygroscopicity ( $\kappa_{\mathrm{a}}$, red dots). In the right column of this figure panels are showing distributions at different times indicated by different colors: (b) particle number size distributions; (d) CCN efficiency spectra at $S=0.66 \%$; (f) $\mathrm{CCN}$ size distributions at $S=0.66 \%$.

\section{ACPD}

13, 32575-32624, 2013

\section{$\mathrm{CCN}$ at the Jungfraujoch}

D. Rose et al.

Title Page

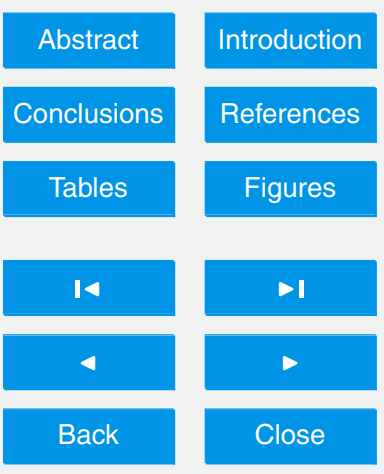

Full Screen / Esc

Printer-friendly Version

Interactive Discussion 


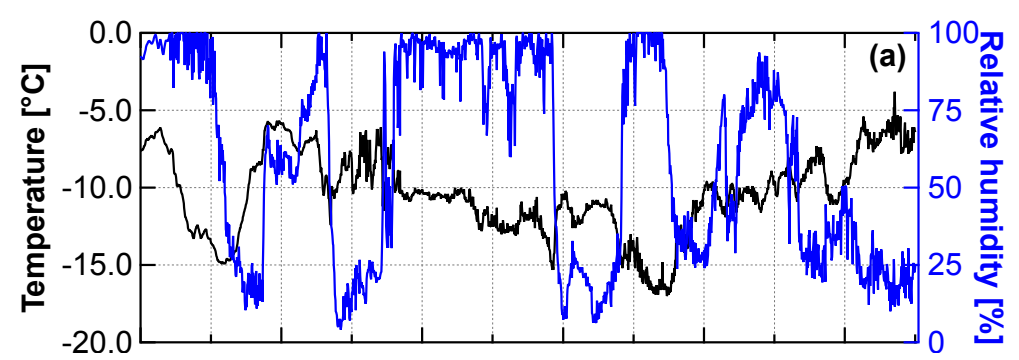

\section{ACPD}

13, 32575-32624, 2013

\section{$\mathrm{CCN}$ at the Jungfraujoch}

D. Rose et al.
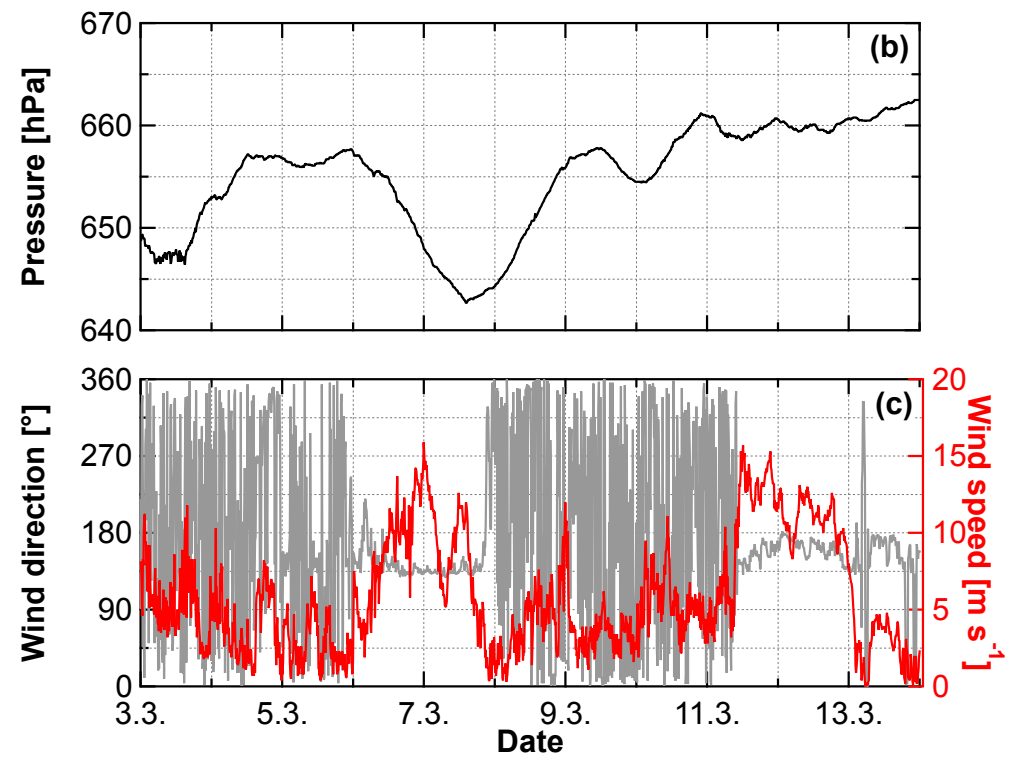

Title Page

Abstract

Conclusions

Tables

14

4

Back Introduction

References

Figures

$\rightarrow$

D

Close

Full Screen / Esc

Printer-friendly Version

Interactive Discussion

Fig. A1. Time series of characteristic meteorological parameters observed in the period of 3 to 14 March during the CLACE-6 campaign: (a) temperature (black) and relative humidity (blue); (b) pressure at the JFJ; (c) wind direction (grey) and wind speed (red). 

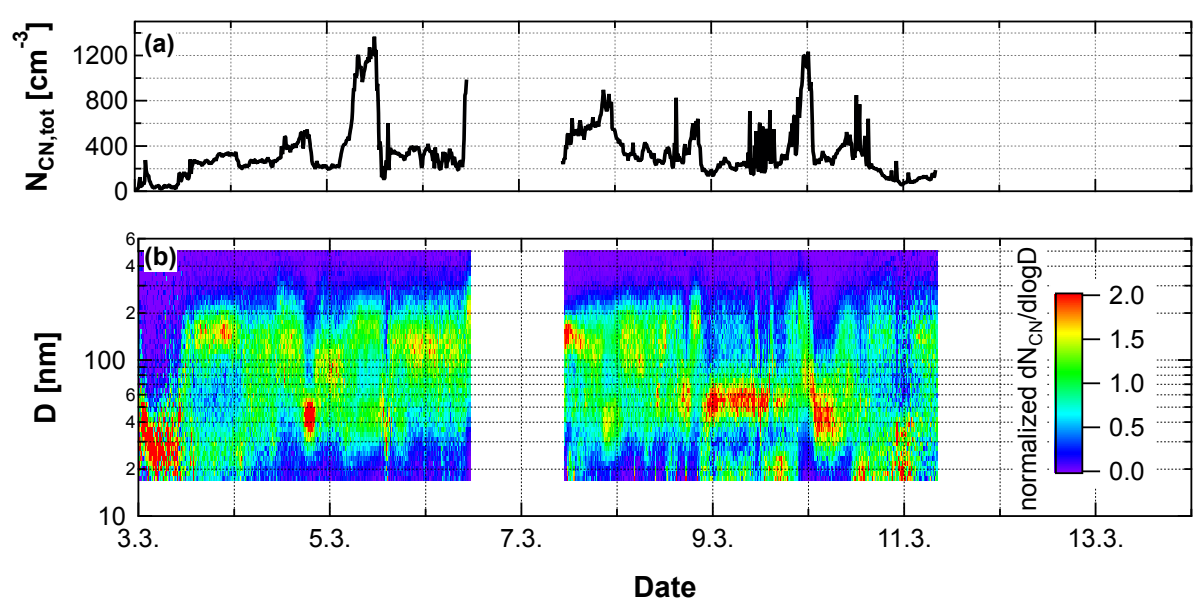

Fig. A2. Time series of (a) the total particle number concentration $\left(N_{\mathrm{CN}, \text { tot }}\right)$ and (b) the particle number size distribution normalized to $N_{\mathrm{CN} \text {,tot }}$. The plots show all available data recorded by the SMPS between 3 to 14 March.

\section{ACPD}

13, 32575-32624, 2013

$\mathrm{CCN}$ at the Jungfraujoch

D. Rose et al.

\section{Title Page}

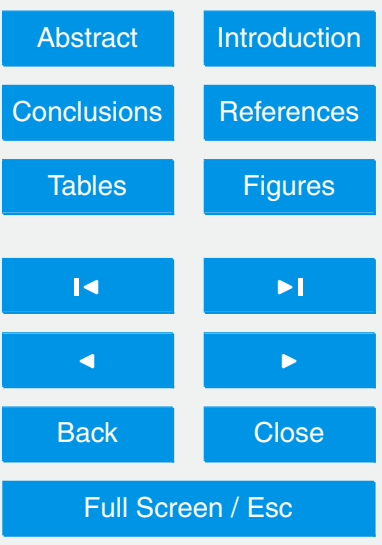

Printer-friendly Version

Interactive Discussion 


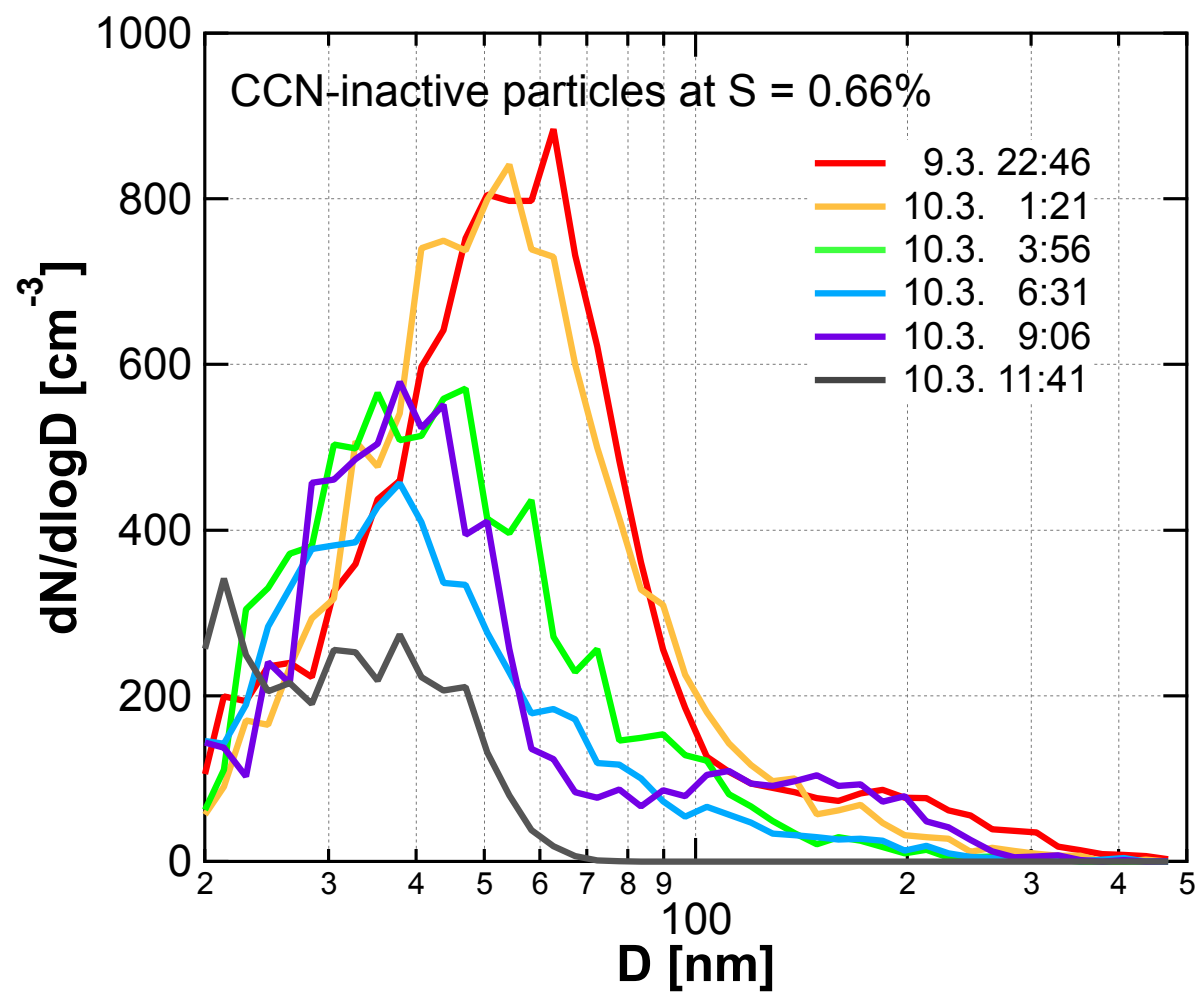

Fig. A3. Number size distribution of particles that are $\mathrm{CCN}$-inactive at $S=0.66 \%$ (difference between $\mathrm{CN}$ size distribution and $\mathrm{CCN}$ size distribution at $S=0.66 \%$ ). Different colors indicate different times between 9 March 21:00 LT and 10 March 12:00 LT (same color code as in Fig. 9).

\section{ACPD}

13, 32575-32624, 2013

CCN at the Jungfraujoch

D. Rose et al.

\section{Title Page}

Abstract

Conclusions

Tables

14

4

Back

\section{Full Screen / Esc}

Interactive Discussion 